\title{
The Performance of Short-term Institutional Trades
}

\author{
Bidisha Chakrabarty \\ Pamela C. Moulton \\ Charles Trzcinka ${ }^{*}$
}

January 22, 2016

\begin{abstract}
* Chakrabarty is at Saint Louis University (chakrab@slu.edu), Moulton is at Cornell University (pmoulton@cornell.edu), and Trzcinka is at Indiana University, Bloomington (ctrzcink@indiana.edu). We thank an anonymous referee, Amber Anand, James Angel, Warren Bailey, Robert Battalio, Azi Ben-Rephael, Stephen Brown (the editor), Martijn Cremers, Luis Goncalves-Pinto, Jeff Harris, Craig Holden, Paul Irvine, Ravi Jain, Bob Jennings, David Jessop, Peter Lerner, Qing Ma, Maureen O’Hara, Kevin Mullally, Anna Obizhaeva, Ajay Patel, Gideon Saar, Sophie Shive, Andriy Shkilko, Anthony Trzcinka, Konstantin Tyurin, Kelsey Wei, Russ Wermers, and seminar participants at Cornell University, Indiana University, Syracuse University, University of Notre Dame, the 2012 India Finance Conference, the 2013 Finance Down Under Conference, the 2013 FMA Conference, the 2014 European Finance Association Conference, and the 2014 UBS Equities Quantitative Investment Conference for helpful comments. We also thank Zhi Da for DGTW benchmark returns, John Hallinger and Andy Puckett for advice on the Ancerno data, Jeff Bacidore for insights into institutional trading, Yifei Mao for research assistance, and Ancerno Ltd. for providing data.
\end{abstract}




\title{
The Performance of Short-term Institutional Trades
}

\begin{abstract}
Using a database of daily institutional trades, we document that a majority of short-term institutional trades lose money. In aggregate, over $23 \%$ of round-trip trades are held for less than three months, and the returns on these trades average $-3.91 \%$ (non-annualized). These losses are pervasive across all types of stocks, with the lowest returns occurring in small stocks, value stocks, and low-momentum stocks. Short-term trades lose more in more volatile markets. Across funds, the worst short-term returns accrue to funds that do the most trading, and there is no evidence of persistent skill or disposition effect in short-term institutional trades.
\end{abstract}

JEL classification: G11, G23

Keywords: Institutional trading, short-term trades, trading skill, information 


\section{Introduction}

This paper documents the surprising finding that the shorter the holding period of an institutional trade, the more negative the return of the trade. We use data on the daily trades of institutions (money managers and pension funds) provided by a vendor hired to examine the trading costs of their clients. Mutual funds and defined-benefit asset managers have strong incentives to earn positive returns. The fact that they hire a vendor to analyze trade execution costs itself suggests that they care about returns. More broadly, Ma, Tang, and Gomez (2015) show that mutual fund managers have performance-based compensation contracts. Furthermore, empirical studies argue that stocks held by institutions are more efficiently priced (Boehmer and Kelley, 2009), better governed (Chung and Zhang, 2011; Ferreira and Matos, 2008), and have lower agency costs (Wang and Nanda, 2011) than stocks held by retail investors, suggesting that institutional traders make informed trades. Yet their short-term trades do not earn positive returns on average. This paper is the first to document this surprising fact and explore possible explanations for this finding.

In contrast to the literature arguing or implying that institutional trades earn a positive return, our finding is consistent with a growing literature that classifies institutions as either "short-term" or "long-term" and finds temporary price distortions when short-term investors dominate trading. For example, Bushee and Noe (2000) show that when a firm's short-term (transient) institutional ownership percentage increases, stock return volatility also increases. Cella, Ellul, and Giannetti (2013) find that short-term institutions create price pressure during episodes of market-wide shocks, driving prices temporarily below the prices of stocks held more heavily by long-term investors. Cremers, Pareek, and Sautner (2014) find that the presence of short-term investors is associated with temporary price distortions and return anomalies. Cremers and Pareek (2015) find that among funds with high active share portfolios, only those with long 
stock holding periods outperform their benchmarks. Taken together, this literature suggests that short-term institutional trades are detrimental to stock pricing. However, none of these studies examine the actual daily trades of institutions. Instead they rely on quarterly $13 \mathrm{~F}$ data to develop statistics that characterize portfolios as short-term or long-term. The use of $13 \mathrm{~F}$ filings for portfolio holdings does not fully reveal the actual holding period of an institution, since firms' intra-quarter round trip trades do not show up in 13F filings.

In a closely related paper, Puckett and Yan (2011) examine trades that take place entirely within a calendar quarter, which is a more limited definition of short-term trades than the set of all short-term trades used in this paper. About $54 \%$ of the under-three-month trades in our sample occur within a calendar quarter, but only about $36 \%$ of these trades match the intra-quarter trades of Puckett and Yan (2011) because of their narrower definition (see Section 2.3). Puckett and Yan show that trades that are initiated and closed (or marked to market) entirely within a quarter produce positive returns, a finding which we replicate in our sample. But portfolio managers know that trades within a quarter will not be disclosed on $13 \mathrm{~F}$ filings and may strategically conduct those trades within a quarter to hide them from competitors. Therefore, round-trip trades that take place entirely within a calendar quarter could very well be different from round-trip trades of the same length that straddle calendar quarters. We suggest that to characterize the returns from short-term trades requires a broader definition of round-trip trades that includes the history of all short-term trades, including those that span days in two calendar quarters. To the best of our knowledge, our paper is the first to examine the trading horizons of institutions using this broader definition.

In this study we examine short-term institutional trades using the entire record of buy and sell transactions in each stock to determine the length of time a fund holds a stock. In examining 
actual trades rather than trades inferred from quarterly holdings, we are also testing the validity of the conclusions drawn from trades inferred from 13F filings, as discussed in detail in section 2. Our sample consists of the daily U.S. equity transactions of 1186 institutional money managers and pension funds that are present in a proprietary database for at least five years. A key advantage is that this database allows us to observe funds' actual buy and sell transactions on a daily basis, rather than relying on proxies such as quarterly changes in holdings. We match stock purchases and sales within each fund to identify the holding periods and returns of over 105 million round-trip trades between 1999 and 2009, with a total volume of over 291 billion shares. We find a surprising incidence of short-duration trades: Over $99 \%$ of the institutional funds execute round-trip trades lasting less than three months, and in aggregate over $23 \%$ of the volume occurs in trades that are held for less than three months.

The prevalence of short-duration trades appears surprising in light of the generally low annual turnover rates reported for mutual funds and pension funds, typically averaging below $100 \%$. But a turnover rate of $100 \%$ could arise from a fund trading all of its positions once a year, or trading half of its positions twice a year and not trading the other half of its positions, or a wide array of other combinations of short- and long-duration trades. Clearly, the greater the dispersion of trade durations that make up a turnover rate, the less informative is the turnover rate about trade durations. ${ }^{1}$ Our dataset of round-trip trades at the fund level provides an inside examination of the trade durations behind fund turnover numbers.

We first examine the round-trip trades by holding period in aggregate for the entire sample. Short-duration trades have negative returns both in general and after adjusting for the performance

\footnotetext{
${ }^{1}$ The Investment Management Association (2011) points out that both the SEC and its European equivalent explicitly state that a fund's turnover rate is meant only to give investors a sense of how portfolio turnover and resulting transaction costs affect fund performance, not to give an indication of trade holding periods.
} 
of characteristic-based benchmarks as in Daniel, Grinblatt, Titman, and Wermers (1997) (DGTW hereafter). For example, trades held less than three months have an average raw (non-annualized) return of $-3.91 \%$, which remains a highly significant $-1.24 \%$ after DGTW adjustment. ${ }^{2}$ The losses occur across all types of stocks, although losses are larger for smaller stocks, value stocks, lowmomentum stocks, and during times of high market volatility.

We next examine the performance of short-duration trades at the fund level, where trading decisions are made. The mean and median fund-level returns for short-duration trades are significantly negative. For example, the mean (median) two-to-three-month trade returns for money managers is $-2.64 \%(-2.94 \%)$, and for pension funds is $-3.37 \%(-3.41 \%)$, both of which remain highly significant and negative after DGTW adjustment. Furthermore, we find that funds with the most short-duration trading, and funds with the most trading overall, tend to have the most negative short-duration trade returns. We find no evidence of skill in short-term trading: Funds that have the highest short-term trade performance in one period do not exhibit superior short-term trade performance in subsequent periods.

Finally, we briefly explore why fund managers engage in so much unprofitable short-term trading. One possible explanation is that fund managers unwind loss-making trades early because they receive new information suggesting that the trades will be even more unprofitable if held for longer. We find no evidence that managers are successfully "cutting their losses"; in fact, we find that on average their short-duration trades would have been profitable had they been held for a year instead of being closed out within three months. This pattern of realizing losses quickly although holding a trade longer would have been more profitable is consistent with a form of recency bias (Tversky and Kahneman, 1973), in which people overweight recent experiences (in

\footnotetext{
${ }^{2}$ These are principal-weighted average returns for trades held less than three months, of which $6 \%$ are held for less than one week, $25 \%$ are held for one week to one month, $35 \%$ are held for one to two months, and $34 \%$ are held for two to three months.
} 
this case, a recent adverse price move). We find no evidence of fund managers exhibiting a disposition effect: Their short-duration trades have negative returns and their longer-duration trades have positive returns on average. While some funds do earn positive returns on their shortduration trades in each period, we find no evidence of persistent skill. Furthermore, funds with the highest short-duration trade returns in one period do not do more short-duration trades in subsequent periods, ruling out attribution-bias-based overconfidence as an explanation.

Our fund-level findings are consistent with fund managers "trading to look active," as modeled in Dow and Gorton (1997). Mutual fund and pension fund portfolio managers are closely monitored by either mutual fund advisors or pension fund clients and usually have performancebased contracts (Ma et al., 2015). Dow and Gorton predict that fund managers who have no information-based reason to trade will nonetheless trade actively if whoever is monitoring them is unable to distinguish between actively doing nothing and simply doing nothing. Since trading to look active is not based on information, such trades are likely to be unprofitable.

These findings make several contributions to the literature. First, our results demonstrate the surprising finding that most institutional trades with holding periods of nine months or less lose money. This finding is new to the literature and emerges directly from our broad identification of round-trip trades. Overall, our results are consistent with the findings from the "short-term institutions" literature which documents that these institutions are not trading on superior information.

Second, our results contribute to other streams in the literature. Corporate finance studies routinely use the percentage of common stock held by institutions as a proxy for the sophistication of the investors holding the security. Our results suggest that the short-term trades of institutions are broadly inconsistent with these views and more in line with agency conflicts and behavioral 
biases. Thus, our evidence supports the use of "long-term investors" (or "dedicated investors" in the terminology of Bushee, 2001) to establish the effects of sophisticated institutional investors rather than treating all institutions as homogeneous.

Third, the literature on delegated portfolio management offers substantial evidence that not all institutional investment decisions are based on information and return-maximization. Mutual funds appear to select stocks based on familiarity (e.g., Coval and Moskowitz, 1999), sell stocks based on the disposition effect (Frazzini, 2005), and earn risk-adjusted returns lower than simple passive strategies (Fama and French, 2010). ${ }^{3}$ For pension funds, the available evidence paints a similar picture (e.g., Busse, Goyal, and Wahal, 2010). Finally, Cremers and Pareek (2015) develop a measure of fund duration and show that "active share" results are driven by funds that hold stocks for two years or more. None of these studies use daily trade records and all base their conclusions on inferences from quarterly holdings. While we show that short-duration institutional trades are broadly inconsistent with decisions made based on information, we reject the disposition effect and attribution-bias-based overconfidence. Our results are consistent with recency bias, previously found only for retail investors (Nofsinger and Varma, 2013), and the agency cost of "trading to look active" by Dow and Gorton (1997).

The remainder of the paper is organized as follows. Section 2 describes our data and sample and details our methodology for identifying round-trip trades. Section 3 presents returns for trades held over different periods. In Section 4 we examine which short-terms trades tend to lose money, and in Section 5 we examine possible explanations. Section 6 discusses robustness checks, and Section 7 concludes. An online appendix provides technical details related to the matching of Ancerno data to CRSP, identifying round-trip trades using different methodologies, comparisons

\footnotetext{
${ }^{3}$ A recent exception to the generally negative assessment of fund managers is provided by Berk and van Binsbergen (2015), who find evidence that mutual fund manager skill exists and is persistent.
} 
to the Puckett and Yan (2011) round-trip trade methodology, and the double-clustered standard errors used throughout this paper.

\section{Data, Methodology, and Sample}

We obtain institutional trading data from Ancerno Ltd., a widely recognized consulting firm that monitors trade execution costs for institutional clients. In order to provide execution cost analysis, Ancerno collects detailed transaction information for all equity transactions executed by each client. Ancerno's clients include pension funds (such as CALPERS, the Commonwealth of Virginia, and the YMCA retirement fund) and money managers (such as Massachusetts Financial Services, Putnam Investments, Lazard Asset Management, and Fidelity). ${ }^{4}$ We also collect stock data from CRSP and Compustat.

\subsection{The Necessity of Identifying Round-Trip Trades}

Our study tests an important implication of the "short-term" institution literature (Bushee and Noe, 2000; Cella et al., 2013; Cremers and Pareek, 2015), that short-term institutions cause price distortions. A common statistic used in these studies to classify an institution as short-term or long-term is the "churn rate" developed by Gaspar, Massa, and Matos (2005). The churn rate for an institution is a measure of how frequently it rotates its position in all its stocks; this number falls in the interval $[0,2]$. If dollar volume of trading is zero, the churn rate is 0 ; if every stock is sold and replaced by another stock at the end of the quarter, the churn rate is 2 . Studies employing the churn rate use holdings reported quarterly and consequently ignore round-trip trading within the quarter and the timing of large trades relative to the stocks held. A simple example of how the churn rate can be misleading is illustrated in Exhibit 1 below:

\footnotetext{
${ }^{4}$ Previous academic studies that use Ancerno data include Goldstein, Irvine, Kandel, and Wiener (2009) and Puckett and Yan (2011). Puckett and Yan (2011) estimate that Ancerno clients represent approximately $10 \%$ of all institutional trading volume.
} 


\section{Exhibit 1: Example of Misleading Churn Rates}

The formula from Gaspar, Massa, and Matos (2005) for a churn rate for fund $i$ at date $t$ is:

$$
C R_{i, t}=\frac{\sum_{j \in Q}\left|N_{j, i, t} P_{j, t}-N_{j, i, t-1} P_{j, t-1}-N_{j, i, t-1} \Delta P_{j, t}\right|}{\sum_{j \in Q} \frac{N_{j, i, t} P_{j, t}+N_{j, i, t-1} P_{j, t-1}}{2}}
$$

where $\mathrm{N}_{\mathrm{j}, \mathrm{i}, \mathrm{t}}$ is the number of shares held of stock $j$ by fund $i$ at date $t$ and $\mathrm{P}_{\mathrm{j}, \mathrm{t}}$ is the price of stock $j$ at date $t$.

\begin{tabular}{|c|c|c|c|c|c|c|c|c|c|c|c|c|}
\hline \multirow[b]{3}{*}{ Stock } & \multicolumn{6}{|c|}{ Buy-and-Hold Portfolio } & \multicolumn{6}{|c|}{ Actively Traded Portfolio } \\
\hline & \multicolumn{2}{|c|}{ Quarter Begin } & \multicolumn{2}{|c|}{ Day 45} & \multicolumn{2}{|c|}{ Quarter End } & \multicolumn{2}{|c|}{ Quarter Begin } & \multicolumn{2}{|c|}{ Day 45} & \multicolumn{2}{|c|}{ Quarter End } \\
\hline & Shares & Price & Shares & Price & Shares & Price & Shares & Price & Shares & Price & Shares & Price \\
\hline $\mathrm{A}$ & 20,000 & 22 & 40,000 & 22 & 40,000 & 22 & 2,000 & 22 & 4,000 & 22 & 2,000 & 22 \\
\hline B & 1,000 & 41 & 1,000 & 41 & 1,000 & 41 & 1,000 & 41 & 500 & 41 & 1,500 & 41 \\
\hline $\mathrm{C}$ & 1,700 & 32 & 1,700 & 32 & 1,700 & 32 & 1,700 & 32 & 2,400 & 32 & 1,000 & 32 \\
\hline $\mathrm{D}$ & 0 & 27 & 0 & 27 & 0 & 27 & 0 & 27 & 750 & 27 & 0 & 27 \\
\hline & 5-day $\mathrm{Ch}$ & Irn Rates: & 0.582 & & 0.000 & & 45-day $\mathrm{Ch}$ & arn Rates: & 0.621 & & 0.875 & \\
\hline & arterly $\mathrm{C}$ & Iurn Rate: & & & 0.582 & & Quarterly C & nurn Rate: & & & 0.310 & \\
\hline
\end{tabular}

In this example, the "quarterly churn rate" applies the formula to the shares and prices based on the beginning and end of the quarter, ignoring the intra-quarter trading revealed at day 45 (as in Gaspar et al., 2005, and subsequent studies). The "45-day churn rate" applies the formula to the shares and prices between the beginning of the quarter and day 45 (halfway through the quarter), and separately to the period from day 45 through the end of the quarter, to provide a more detailed view of each portfolio's trading. The prices never change so the different churn rates are driven only by trading. The quarterly churn rate for the buy-and-hold portfolio (on the left) is almost twice as large as the actively traded portfolio (on the right), but it is entirely driven by one large trade in stock A. The buy-and-hold portfolio has constant holdings in stocks B, C, and D and clearly does not fit the "short-term" definition described by the literature examining short-term institutions. The actively traded portfolio, on the other hand, is obviously more short-term, yet it has a much lower churn rate. The lower churn rate occurs because the actively traded portfolio reverts to close to its beginning-of-quarter holdings at the end of the quarter. If it reverted to exactly the same holdings its churn rate would be zero. Of course, large price changes can offset the 
differences between the two portfolios, but in this example the price of stock A would have to fall by more than $50 \%$ to equalize the two churn rates.

This simple example demonstrates how a statistic derived from quarterly filings to infer portfolio holding periods may not reflect the actual holding period of an institution. Even a widely accepted statistic like the churn rate can be misleading since intra-quarter trades can offset shortterm trades, driving the churn rate down, yet such intra-quarter trades still signal the short-term focus of an institution. In addition, trading volume in a small number of stocks can easily bias this measure. We note that the use of churn rates may be clearly powerful for some classes of investment decisions such as the large responses by institutions to market-wide volatility (Cella et al., 2013), since quarterly holdings are likely to be dramatically affected in the same direction for all institutions. If most prices in the market move in the same direction and most institutions that trade do so in roughly the same direction, then the churn rate will capture differences between institutions. For normal market periods, the churn rate is a noisy proxy for holding periods and an examination of actual holding periods is warranted.

\subsection{Identifying Round-Trip Trades}

To identify round-trip trade holding periods, we match buy and sell transactions for the same stock within the same fund. We use both the first-in-first-out (FIFO) and last-in-first-out (LIFO) methods since there is no consensus on which method should be used to match buy and sell transactions into round-trip trades. On one hand, a consultant to institutional fund managers told us that "the clock starts when you enter the trade," implying the FIFO approach may be more appropriate. On the other hand, LIFO may more accurately capture the change in opinion or information that causes a manager to switch from buying to selling or vice versa. In most of our analyses, the FIFO and LIFO trade matching methodologies yield identical inferences, so we 
present only results based on the FIFO methodology; where the results differ materially we present and discuss both.

From the 2010 Ancerno database, we obtain the following information for each transaction: the ticker symbol of the security (symbol), the transaction date (tradedate), the identifier for the institution (clientcode), such as Fidelity or Putnam, the identifier for the fund within an institution (clientmgrcode), such as Fidelity Magellan or Fidelity Equity Income fund, the transaction direction (side, which is 1 for buy and -1 for sell transactions), volume of shares transacted (volume), and transaction price (price). All clientcodes and clientmgrcodes are expressed as numbers, so although we can identify all the transactions executed by the same institution or the same fund, we cannot determine the identity of the institution or fund. For each symbol-clientcodeclientmgrcode combination, we use data from January 1997 to December 2009 to identify roundtrip trades. A round-trip trade for a stock is defined as a purchase and a sale of the same number of shares in the same fund (identified by clientcode-clientmgrcode).

It is worth mentioning that the composition of the Ancerno database has changed since the version that we use. These changes include name changes for some variables and revelation of the identities of funds. It is important to our research design that the funds know their trades will be kept confidential and that there is a clean match between fund and fund family. It appears that Ancerno has complicated this match in subsequent database releases. The database we use is similar to the one used in Hu, McLean, Pontiff, and Wang (2014), who also discuss these changes.

To identify the FIFO-based (LIFO-based) round-trip trades, we assemble the transaction information for each symbol-clientcode-clientmgrcode combination chronologically into a queue, and when a transaction in the opposite direction enters the queue, we match it with the earliest (most recent) existing transaction in the queue. The number of trading days between the buy 
transaction and the sell transaction is the holding period of the round-trip trade, and the number of shares bought and sold (which are equal under the definition of a round-trip trade) is the roundtrip trade quantity. We provide examples of our FIFO and LIFO trade matching procedures in the online appendix.

We note that the Ancerno dataset has no information on a fund's holdings at any time; only transactions are reported to Ancerno. Our method effectively initializes each symbol-clientcodeclientmgrcode combination with zero shares, and we discard the first two years of the dataset because Ancerno coverage is sparse (as in Anand, Irvine, Puckett, and Venkataraman, 2013, and Goldstein et al., 2009). All of our analyses are based on round-trip trades from the sample period January 1999 to December 2009.

We apply the following filters to remove potentially misleading or erroneous trades. We discard all trades with clientcode equal to zero, which indicates that Ancerno cannot reliably track the fund over time. We also discard trades with buy price or sell price less than one cent. To ensure that the number of shares traded and the trade prices are comparable between the buy and sell dates, we exclude round-trip trades in which the buy and sell dates straddle a stock split date, e.g., the stock was bought before a split date and sold after the split date. ${ }^{5}$ Approximately $6 \%$ of the FIFO round-trip trades (5\% of the LIFO round-trip trades) are eliminated from our sample by this screen; fewer LIFO trades are eliminated because they tend to be shorter and span fewer of the stock split dates. Finally, we exclude intraday trades (in which a fund buys and sells the same stock on the same day) because intraday timestamps in Ancerno are incomplete (e.g., Anand et al., 2013).

\footnotetext{
${ }^{5}$ From CRSP, we identify 4800 stock splits and stock dividends (CRSP DISTCD $=5523,5533,5543$ ) involving 2795 stocks in our sample. (See online appendix for details of matching Ancerno data to CRSP.) We note that the inclusion of dividend distributions in this filtering treatment is a conservative approach. If managers typically keep the shares they receive as a stock dividend, retaining trades straddling dividend dates will affect the quantity in the calculation of round-trip trades; however, if managers automatically convert dividend distributions into cash, stock dividends would be immaterial to our round-trip trade calculations. Since we cannot identify which action specific managers adopt with respect to stock dividends, we discard all roundtrip trades straddling stock dividend distributions as well as stock splits.
} 


\subsection{Differences from Puckett and Yan (2011) Methodology}

To assemble our sample, we form a queue of all buys and sells a fund makes in a stock from the beginning of the Ancerno database and match the buys with sells using either the FIFO or LIFO rule to determine trade holding periods and returns. In contrast, Puckett and Yan (2011) examine all buys and sells within a stock-quarter and identify intra-quarter round-trip trades if the same fund has both buys and sells for a stock within a quarter, calculating returns using a weighted average price, FIFO, or LIFO. The Puckett and Yan method effectively starts with a clean slate at the beginning of each calendar, while our method considers how a fund's trading before a quarter affects the interpretation of trading within the quarter. As a result, the two methodologies can give rise to starkly different identification of short-term trades that occur within a calendar quarter, and the round-trip trades identified under different methods are not subsets of each other. ${ }^{6}$ Examples of how the two methodologies can give rise to different and non-overlapping trade categorizations are provided in the online appendix.

We believe that using the entire pattern of trading best represents the round-trip trades for the purpose of investigating questions raised in the literature about the information content of short-term institutional trades. To determine whether the average institutional portfolio manager is skilled and/or informed it is necessary to look jointly at all his trading decisions and the times at which these decisions are made.

\footnotetext{
${ }^{6}$ The key difference between Puckett and Yan's analysis and ours is that we are interested in trade holding periods, while Puckett and Yan are specifically interested in intra-quarter trading. This distinction leads to different trade classifications in our study versus theirs. For example, a trade initiated on January 15 and closed out on March 15 the same year would be considered an interim round-trip trade by Puckett and Yan (2011), but a trade initiated on March 15 and closed out on May 15 the same year would not; both trades would be categorized as two-month trades in our study. Conversely, a trade initiated on March 15 and closed out on September 15 the same year would be marked to market on March 31 in Puckett and Yan's interim trading performance measure; in our study, the trade would be categorized as a six-month trade and would not be marked to market on March 31.
} 


\subsection{Sample Descriptive Statistics}

Table 1 presents descriptive statistics for the full sample of FIFO round-trip trades and for the subsample of trades made by funds that are present in the Ancerno universe for at least five years. ${ }^{7}$ A natural concern when analyzing trade holding periods is whether the incidence of shortduration trades is unduly influenced by the presence of funds that remain in the universe for only a short period of time. For example, we obviously cannot observe round-trip trades longer than one year for a fund that is in the universe for only one year. Of the 4053 unique funds appearing in the universe between 1999 and 2009, 1059 funds are present for one year or less, and 1186 funds are present for five or more years. In Table 1 we present descriptive statistics for both the full sample of 4053 funds and the subsample of 1186 funds that are present for at least five years, which are the focus of our study; in the remainder of the paper we present results only for the sample of funds present for at least five years.

\section{[Table 1 here]}

Panel A of Table 1 shows that the 4053 funds in the full sample belong to 772 distinct institutions; the subsample of 1186 funds present for five or more years belong to 324 distinct institutions. In both samples the median institution has three funds. In the full sample, there are over 328 billion shares and over $\$ 10$ trillion in round-trip trades. ${ }^{8}$ Although only $29 \%$ of the funds in Ancerno are present for five or more years (1186 of the 4053 funds), they account for about $88 \%$ of the share volume and dollar volume in the full sample. These long-lived funds also trade over $96 \%$ of the stocks traded in the full sample. In both the full sample and the subsample of

\footnotetext{
${ }^{7}$ Table 1 for LIFO round-trip trades is virtually identical and available on request.

${ }^{8}$ We note that the number of round-trip trades, also reported in the table for completeness, may not be as informative for estimating liquidity as the volume statistics, both because the average size of equity trades falls considerably during the sample period (Chordia, Roll, and Subrahmanyam, 2011) and because in some cases our identification of round-trip trades counts orders that are executed in multiple pieces as separate trades. Hvidkjaer (2008) provides evidence that institutions increasingly engage in order splitting strategies resulting in more small trades originating from large institutional investors.
} 
funds present five or more years, the majority of the funds are pension funds, but the majority of trading is done by money managers. For example, among the funds present five or more years, money managers represent only seven percent of the funds but account for over $93 \%$ of the share volume traded. We analyze money managers and pension funds separately because their differences may lead to different inference (e.g., Lakonishok, Shleifer, and Vishny, 1992).

Panel B of Table 1 shows that the trades in both the full sample and the subsample of funds present for five or more years are heavily weighted towards large-capitalization stocks. Over $80 \%$ of the share volume in each sample occurs in stocks in the two largest market-capitalization deciles, while less than half a percent of the share volume occurs in the two smallest deciles. This pattern of institutional trading volume being concentrated in large-cap stocks is consistent with the literature on institutional holdings. For example, Lewellen (2011) finds that between 1980 and 2007, large-cap stocks (above the NYSE $80^{\text {th }}$ percentile) account for over $80 \%$ of institutional holdings, while micro-cap stocks (below the NYSE $20^{\text {th }}$ percentile) constitute about one percent of total institutional holdings.

Table 2 presents the breakdown of institutional round-trip trades by holding period, from less than one week to four or more years. Panel A shows the breakdown for round-trip trades identified using the FIFO method, and Panel B shows analogous breakdowns using the LIFO method. The columns labeled "Aggregate Shares" in each panel report holding-period share percentages calculated across all trades in each sample. A significant portion of trades are held for short holding periods. For example, using the FIFO method (Panel A), over seven percent of share volume occurs in trades with round-trip durations of less than one month and over $23 \%$ of share volume occurs in round-trip trades lasting less than three months (see Aggregate Shares, Cumulative \% column). Using the LIFO method to identify round-trip trades results in even more 
short-duration trades, mainly for the mechanical reason that the LIFO method matches a transaction to its most recent preceding opposite-side transaction, rather than the longest-ago opposite-side transaction under FIFO. Panel B shows that using the LIFO method, over 27\% of share volume occurs in trades held less than one month and over $48 \%$ in trades held less than three months (Aggregate Shares, Cumulative \% column).

\section{[Table 2 here]}

Further insight is provided by the cross-sectional fund-level statistics in the last four columns of Table 2, which report the mean and median across the individual funds' cumulative percentages. While the mean and median fund-level cumulative percentages are broadly in line with the aggregate cumulative percentages, money managers on average do more short-duration trades than pension funds, and the shortest-duration trades are more concentrated in a smaller number of funds. For example, Panel B shows that in aggregate $11.83 \%$ of share volume occurs in LIFO trades held less than one week (Panel B, Aggregate shares, Cumulative \%), but the average money manager and pension funds, respectively, have only $6.86 \%$ and $1.98 \%$ of their share volume in trades held less than one week. ${ }^{9}$ Because we are interested in the behavior of individual fund managers, our subsequent analyses will examine fund-level behavior as well as the aggregate sample of trades.

Figure 1 provides further insight into the prevalence of short-duration trades at the fund level. The incidence of short-duration trades is not driven by only a few extremely active funds: Of the 1186 funds that are present for five or more years, only 43 funds engage in no round-trip trades lasting less than one month based on the FIFO method of identifying round-trip trades (top graph). Of the other 1143 funds, trades lasting less than one month account for 1-3\% of trading

\footnotetext{
${ }^{9}$ Note that the aggregate share measures simply sum across all shares traded, irrespective of the funds in which they occur, so they are not equal to a weighted average of the mean for money managers and the mean for pension funds.
} 
volume in 477 funds, 3-6\% of trading in 343 funds, $6-10 \%$ of trading in 180 funds, and over $10 \%$ of trading in the remaining 143 funds. The remaining graphs in Figure 1 depict the analogous fund frequency distributions for trades defined under the LIFO method and for trade holding periods of less than three months.

\section{[Figure 1 here]}

\section{Holding period returns}

The key finding of the studies that use churn rates is that short-term trading is not necessarily based on economic fundamentals of the stocks. If short-term trades are based on economic fundamentals (or successfully anticipating flows from other traders), the trades should result in positive returns on average. Table 3 presents average raw returns (Panel A) and DGTWadjusted returns (Panel B) for round-trip trades by their holding periods; trade returns are weighted by principal amount (initial share price times number of shares) within each holding period category. The raw return is the percentage price change in the stock. The DGTW-adjusted return is raw return of each stock minus the DGTW benchmark return, where the DGTW benchmarks are the value-weighted returns to portfolios of stocks sorted into quintiles by size, book to market, and past returns, yielding 125 portfolios. ${ }^{10}$ The returns calculated here should be viewed as the upper limit on a trade's true profit because they are based on transaction prices, which include the cost of the bid-ask spread but exclude explicit transaction costs such as commissions. The column labeled "Aggregate Trade Returns" reports average raw and DGTW-adjusted returns across all trades in each holding period. We also calculate the raw and DGTW-adjusted returns for the trades of each fund in each holding period category and present the mean and median fund returns for trades in each duration bucket. The last eight columns of each panel (labeled "Fund-level Trade

10 Details of DGTW benchmark are available on Russ Wermer's website http://alex2.umd.edu/wermers/ftpsite/Dgtw/ coverpage.htm. We thank Zhi Da for providing the daily equivalents of the DGTW benchmark returns for our sample. 
Returns") examine the dispersion of trade returns across funds, separately for money managers and pension funds.

\section{[Table 3 here]}

Our first question is whether the prevalence of short-duration institutional trades indicates that institutional fund managers are primarily exploiting short-lived information advantages (which could be either fundamental or flow-based). The aggregate trade returns column in Table 3, Panel A, shows that the average raw return is significantly negative for trades held less than two years and significantly positive for trades held longer than two years. ${ }^{11}$ Adjusting returns with the DGTW-based benchmarks (Panel B) also indicates that short-duration trades have significantly negative returns, although here the aggregate returns become significantly positive earlier (at the six- to nine-month holding period). The fund-level trade return columns echo the conclusions drawn from aggregate returns. The mean and median returns across the short-duration trades of funds are mostly significantly negative for horizons less than a year. In short, Table 3 does not support the hypothesis that short-term trading reflects short-lived information advantages.

These results contrast sharply with Puckett and Yan (2011), who find positive returns for intra-quarter trades (see their Table 2) and for buys and sells that are marked to market at the end of the quarter (see their Table 3). As we explain in Section 2.3, Puckett and Yan's trades are not a subset of ours because of the influence of the queue, but there is certainly a substantial overlap. In work available from the authors, we use the Puckett and Yan method of constructing round-trip trades and contrast it with intra-quarter trades as defined by looking at the entire queue (our main method). Focusing on Puckett and Yan's 1999-2005 sample period, we find that their method

\footnotetext{
${ }^{11}$ The aggregate return of $-3.91 \%$ quoted in the abstract is calculated by principal-weighting the returns from the first four holdingperiod categories: $6 \%$ of the under-three-month trades are held for one day to one week, $25 \%$ are held for one week to one month, $35 \%$ are held for one to two months, and $34 \%$ are held for two to three months.
} 
produces a $3.26 \%$ mean return in our sample, of similar magnitude to the $2.99 \%$ reported in Table 2 of Puckett and Yan (2011). The correlation of the median returns between our FIFO and Puckett and Yan's is $67 \%$. We would not expect to exactly match their returns because we focus on funds present for five or more years and exclude stocks that split. Using the full information in the queue of buys and sells, our intra-quarter round-trip trades average $-1.94 \%$ for FIFO and $-0.24 \%$ for LIFO over the same 1999-2005 period, with both averages significantly different from zero. Thus the general conclusion of Puckett and Yan (2011) that managers have informed trades that are hidden from 13F filings (i.e., within calendar quarters) is supported. What is not valid is a broader conclusion that institutional short-term trading produces positive returns on average. ${ }^{12}$

Our results are consistent with recent evidence on fund returns. Using bootstrap methods, Kosowski, Timmerman, Wermers, and White (2006) conclude that there is statistically significant evidence of information advantages for only a small group of mutual funds, while Fama and French (2010) conclude there is no such evidence. For managers of funds with institutional clients such as pension funds, Busse, Goyal, and Wahal (2010) conclude that there is only weak evidence of informational advantages. At a minimum, it appears that information advantages are rare enough that they are unlikely to explain the majority of short-term trades.

\section{Which short-term trades lose money?}

A natural question is whether the loss-making short-term trades have certain characteristics in common. For example, are the losses concentrated in a certain type of stocks or during particularly volatile markets, or do they occur mostly in funds that do a lot of trading? To shed some light on these questions, we perform portfolio sorts on stock and fund characteristics. Our

\footnotetext{
12 Puckett and Yan (2011) are careful to conclude that their findings apply only to their definitions of intra-quarter round-trip trades. Other papers are not as careful. For example Griffin, Shu, and Topaloglu (2012) state on page 28 "Puckett and Yan (2011) find that short-term institutional trading earns abnormal returns".
} 
sorting variables include stock beta (from CRSP), size (market capitalization from CRSP), illiquidity (using the illiquidity measure from Amihud, 2002), book-to-market ratio (from CRSP and Compustat), momentum (calculated using a 12-month lookback window, as in Asness, Moskowitz, and Pedersen, 2013), and market volatility (calculated as monthly volatility of S\&P 500 index). At the fund level, we sort on the average annual percentage of dollar volume that is in trades held less than three months, the average annual dollar volume of all round-trip trades, and the average size of trades held less than three months. The latter two sorts are proxies for fund size, which we cannot measure directly because our dataset contains no information on fund holdings; the Ancerno database contains transactions only. Quintile rankings are determined annually across all stocks or funds with short-term trades in that year. Table 4 presents the DGTW-adjusted return results of the sorts at the stock level (Panel A) and the fund level (Panel B).

\section{[Table 4 here]}

Looking first at Panel A, the sorts on stock characteristics show that the poor performance of short-term trades occurs in most stock categories. Returns are lowest in the smallest stocks (Size quintile 1), where information asymmetry is likely to be greatest. Returns are also lower for stocks in the highest book-to-market quintile, i.e., value stocks (Book/Market quintile 5), which is not surprising given the consistent finding that value portfolios earn higher returns over horizons of two to three years (e.g., Asness et al., 2013). Our finding that short-duration trades of stocks in the lowest momentum quintile have very negative DGTW returns $(-6.25 \%)$ is consistent with prior research. The stocks in Q1 are exactly the stocks that should be sold short, but these institutional trades are long. It is worth noting that the stocks in Q5 are the stocks typically bought in momentum portfolios. Q5 shows the largest positive number in the table and is roughly the magnitude found in momentum studies (e.g., Asness et al., 2013). Short-duration trade returns are also significantly 
lower during times of high market volatility, which may reflect both the higher implicit cost of trading during volatile times and a higher likelihood of managers closing out positions for behavioral reasons during volatile times. Returns on short-term trades do not appear to vary monotonically with stock betas or stock illiquidity.

Panel B of Table 4 analyzes money manager and pension funds separately, as they may have different horizons and motivations. Among pension funds, funds that have the highest percentage of short-term trades tend to have the lowest short-term trade returns. Thus the percentage of short-duration trades across funds seems to be inversely correlated with expertise in short-term trading. Funds with the largest amount of trading per year and largest average trade sizes, two proxies for fund size, also tend to have the lowest returns on short-term trades, suggesting that bigger funds do not exhibit more skill (and even exhibit significantly less skill) at short-term trading. The differences across money manager funds are generally not significant, perhaps because there are only 84 money manager funds in our sample, limiting our ability to detect statistically significant differences across fund quintiles.

Overall, the picture that emerges is that the poor returns on short-duration institutional trades are not confined to a particular subset of stocks or type of funds. Nonetheless, some funds do earn positive returns on short-duration trades (e.g., in Table 3 the $75^{\text {th }}$ percentile is positive in almost all short-term holding periods), which could be due to trading skill not correlated with the dimensions captured in Table 4 or simply luck. To examine the extent to which fund manager skill can explain the fund-level results, we next examine the persistence of funds' short-duration trade performance.

[Table 5 here] 
Table 5 presents the results of tests for return persistence for short-duration trades at the fund level. In each semiannual period we sort funds into quintiles based on their performance for trades held less than three months. Note that the returns reported are for a particular category of trades within each fund, not for the fund's overall performance. ${ }^{13}$ We report the average DGTWadjusted return for funds in each quintile in the base semiannual period (when the funds are assigned to quintiles) and in the four subsequent semiannual periods. For example, Panel B shows that the best-performing quintile of pension funds in short-term trades earned an average of $14.17 \%$ in the base period (Panel B, Base period column, Q5 row), while the worst-performing quintile of funds earned an average of $-18.81 \%$ (Panel B, Base period column, Q1 row). The difference of $32.98 \%$ between the best and worst-performing quintiles is statistically significant, with a $t$ statistic of 17.0. Statistical significance in all of our tests is based on standard errors that are double-clustered on fund and semiannual period (see online appendix for details). Although the differences are smaller in subsequent semiannual periods, they are statistically significant. However, the performance difference between Q1 and Q5 is driven mainly by the significant underperformance of the funds in Q1 in all periods subsequent to portfolio formation. Those pension funds with the least skill in trades held less than three months continue to exhibit poor returns in the subsequent four semiannual periods, a pattern that is repeated for money managers (Panel A) but with reduced magnitudes. ${ }^{14}$ In summary, the return persistence results do not appear to be driven by information advantages even for those funds that earn the highest returns.

\footnotetext{
${ }^{13}$ Because we do not have information about a fund's holdings, only its transactions, we cannot calculate a fund's overall performance.

${ }^{14}$ The weaker significance for money managers may in part reflect the small number of money managers in the sample: 84 money managers versus 1102 pension funds.
} 


\section{Why do short-term trades lose money?}

In this section we investigate several possible explanations for the widespread low returns on short-duration trades, in an attempt to understand why fund managers engage in trades that appear to persistently lead to losses. These include the disposition effect (Shefrin and Statman, 1985), loss-cutting, recency bias (Tversky and Kahneman, 1973), overconfidence (Gervais and Odean, 2001), and trading to look active (Dow and Gorton, 1997). While many of these behavioral biases have been documented for individual investors, Frazzini (2005) finds evidence that mutual fund managers are also subject to the disposition effect, suggesting that fund managers may suffer from behavioral biases as well.

Disposition effect. The disposition effect predicts that fund managers sell winners and hold on to losers, which would result in higher returns for shorter-duration trades and lower (or negative) returns on longer-duration trades. The pattern of returns by trade holding period in Table 3 reveals no evidence of the disposition effect, as managers do not appear to sell winners and hold onto losers, at least if we assume that the purchase price is the reference price. But our results are consistent with Ben-David and Hirshleifer's (2012) finding that, contrary to the standard predictions of the disposition effect, at short holding periods individual investors are more likely to sell stocks with big losses than those with small losses.

Loss-cutting. One plausible explanation for negative returns on short-term trades is that fund managers unwind loss-making trades early because they receive new information suggesting that the trades will be even more unprofitable over the longer term, so they "cut their losses." To examine this possibility, in Table 5 we perform the following simulation. For each trade that is held for less than three months, we calculate what its return would have been if it had been held for the rest of a full year (where average fund-level returns turn positive in Table 3). For example, 
if a trade was initiated on March 15, 2006, and closed out on April 1, 2006, we calculate its hypothetical "what-if" return if it had been held from April 1, 2006 to March 15, 2007.

\section{[Table 6 here]}

The results in Panel A of Table 6 show that in aggregate and at the fund level, the mean and median trades that were actually held less than three months would have produced a positive raw return had they been held for the remainder of a year. A similar picture emerges in Panel B, where the DGTW-adjusted returns for the what-if trades are generally positive or near zero. This suggests that the negative returns earned on short-duration trades are not explained by fund managers cutting their losses in light of new information received shortly after they initiate trades.

Recency bias. The combination of negative short-term returns followed by higher returns if the trades had been held longer is consistent with managers demonstrating recency bias. Recency bias is the heuristic in which a person evaluates the probability of events by the ease with which relevant instances come to mind. It creates a tendency to overemphasize recent events, for example a recent return of large magnitude, and has been found to impact stock selection for retail investors (Nofsinger and Varma, 2013; Shefrin, 2007). Using the heuristic, when a manager observes a sharp fall in stock price shortly after buying a stock, he tends to overreact and close out the position, or in practitioner vernacular "abandon his thesis," leading to a short-duration trade at a loss (as in Table 3), although the position would have produced a positive return if it had been held longer (as shown by the what-if trade returns in Table 5). ${ }^{15}$ Ideally a test for recency bias would examine a fund's entire holdings to determine whether funds are more likely to close out trades after observing adverse price moves; unfortunately, the Ancerno dataset contains only funds'

\footnotetext{
${ }^{15}$ Reconstructing the "what-if" returns of Table 5 by including the initial holding period in the one-year returns, that is, by beginning the simulated returns from the initiation date of the trade, produces returns that are (not surprisingly) very close to adding the negative returns of Table 3 to the positive returns of Table 5 .
} 
transactions, not their entire holdings, so such an analysis is not possible in our sample. However, the pattern of returns in Table 4 is consistent with recency bias. Institutions appear to be selling value stocks too soon and going long stocks that are typically shorted in momentum portfolios. This suggests an opportunity for further research using both portfolio holdings and trade horizons.

Overconfidence. To explicitly test for overconfidence, we examine the link between returns and subsequent short-duration trading activity. When combined with attribution bias, overconfidence predicts that following a period of high realized returns, investors mistakenly attribute the returns to their own skill and as a consequence tend to trade more in subsequent periods. The reverse should occur for low returns.

In Table 7 we sort funds into quintiles based on their short-duration trade returns in the base period (as in Table 5), and we report the average percentage of short-duration trading (rather than the trade returns) in the base period and each subsequent period. In most cases the amount of short-duration trading is not higher in subsequent periods for funds with the highest base-period returns (Quintile 5) than for funds with the lowest base-period returns (Quintile 1). Comparing Q5 and Q1, we find that for both money managers and pension funds, the difference in short-duration trading is statistically insignificant for most periods subsequent to portfolio formation. ${ }^{16}$ Indeed, the few significant differences show more short-term trading for funds with the lowest short-term trade returns, the opposite of what would be expected from overconfident managers who mistakenly attribute performance to their skill. Overall, the picture that emerges suggests that

\footnotetext{
${ }^{16}$ Statistical significance in all of our tests is based on standard errors that are double-clustered on fund and semiannual period (see online appendix for details).
} 
whatever overconfidence fund managers may be exhibiting is not directly related to attribution bias. $^{17}$

\section{[Table 7 here]}

Trading to look active. Trading simply to show that a portfolio manager is active, as modeled by Dow and Gorton (1997), should lead to more short-duration trades with low returns, as they are undertaken to justify their management fees rather than to maximize returns. At a minimum such trades would be expected to lose the bid-ask spread, but given their lack of information, they may also lose a great deal more, for example if they inadvertently trade against better-informed investors. Our findings of widespread losses in short-term trades are consistent with fund managers trading simply to look active. That pension funds have lower mean and median fund returns on short-duration trades than money managers suggests that trading to look active may be a larger problem for pension funds, perhaps because the nature of their contracts encourages them to trade more actively just to show they are doing something (Lakonishok et al., 1992).

In summary, the losses on short-term trades appear most consistent with managers trading to look active or suffering from recency bias, which causes them to overweight recent adverse price moves in their trading decisions. We find no evidence of the disposition effect, loss-cutting, or attribution-bias-related overconfidence.

\footnotetext{
${ }^{17}$ Other aspects of overconfidence are still possible. For example, Moore and Healy (2008) define three dimensions of overconfidence: overestimation is the biased estimation of the chance of success, overprecision is the excessive certainty about the accuracy of one's beliefs, and overplacement is when people believe they are better than others. Our results suggest that overestimation and overprecision based on previous returns do not occur in these trades, but overplacement is still a possibility.
} 


\section{Robustness checks}

Results for the full sample of funds in the Ancerno universe (4053 funds) are qualitatively similar to those presented in the paper (which are based on the 1186 funds present for five or more years), with the exception that the full sample implies that a larger proportion of trades are shortduration, a mechanical result because funds that are present for only a short period of time can contribute only short-duration trades. All of our findings are qualitatively similar when we use one month instead of three months as the cutoff for our definition of short-duration trades. Results are not driven by the financial crisis of 2008; all results are qualitatively similar when 2008 is dropped from the sample period. Alternative measures of market-wide volatility including the VIX index and range-based measures of S\&P 500 index volatility yield qualitatively similar results. Using the Fong, Holden, and Trzcinka (2014) measure of illiquidity suggests that short-term trades in the most illiquid stocks have significantly lower returns. A multivariate regression of short-duration (DGTW-adjusted) trade returns on stock and fund characteristics provides similar inferences to those provided by the univariate tests in Table 4. As an alternative to DGTW adjustments, we also replicate our analyses with market-adjusted returns, defined as raw returns minus returns on the S\&P 500 index over the identical holding period for each trade. All of our conclusions hold.

We also investigate whether cross-trading (internalization) among funds of the same institution may explain our results. Chaudhuri, Ivkovic, and Trzcinka (2014) find evidence that institutions cross-trade in order to benefit one fund at the expense of another, behavior about which the Pension and Welfare Benefits Administration of the U.S. Department of Labor has expressed serious concern (U.S. Department of Labor, 1998). We identify potential cross-trades when the same stock is bought by one fund and sold by another fund belonging to the same institution, at 
the same price on the same day. Potential cross-trades account for less than $0.001 \%$ of the total share volume in our sample, and excluding them from our analyses does not change our results.

\section{Conclusion}

This is the first study to document that the majority of short-duration institutional trades lose money, using a large database of institutional trades. We examine a wide range of actual trade holding periods of institutional investors, from one-day trades to those held for multiple years, using the entire available history of an institution's trading. Analyzing the daily U.S. equity trades of 1186 institutional funds present in the Ancerno database for at least five years, we identify holding periods and returns of over 105 million round-trip trades between 1999 and 2009, with a total volume of over 291 billion shares. We find that short-duration trades are common in institutional portfolios. In aggregate over $23 \%$ of volume occurs in trades that are held for less than three months. Within the less-than-three-month category are a significant number of trades that are held for less than a month and even less than a week. The prevalence of short-duration trades appears surprising in light of the typically low turnover rates for mutual funds and pension funds.

The average returns for trades held for nine months or less are overwhelmingly negative, with the lowest returns occurring in small stocks, value stocks, and low-momentum stocks. Shortduration trade returns are also lower when the market is more volatile. At the fund level, funds that do the most short-duration trading also have the lowest short-duration trade returns, and we find no evidence of persistent skill in short-duration trades.

The negative returns on short-duration trades do not appear to be due to loss-cutting when managers receive new information after initiating a trade, since the returns would have been positive on average if managers had held the positions for a year. That short-term trades have negative returns on average rules out the disposition effect. We show that the relatively few 
successful short-term trades do not lead to more short-term trading in the same fund, which rules out attribution-bias-based overconfidence. Short-duration trades may be driven by recency bias, with managers selling after a sharp adverse price move. In the practitioner vernacular, the manager "abandons his thesis" when the stock price goes against his trade. Our results are also consistent with the agency problem that arises when clients cannot distinguish when a manager is "actively doing nothing" versus "simply doing nothing." By trading when they have no particular information, fund managers expose themselves to losses both from the bid-ask spread and from possible adverse selection if they trade with better-informed traders.

This study presents a richer picture of institutional trading decisions, providing insight into the many findings in the literature that are based on characterizing institutions as short-term versus long-term. By looking at precise trades rather than net changes in quarterly portfolio holdings, we are able to reveal the true short-term trading activity of institutions, which can be masked by using "churn rates". From this microfoundation, it is easier to understand why the presence of short-term institutions (defined as institutions who engage in more short-term trades) is found to be associated with temporary price distortions and return anomalies.

Our results demonstrate that the conclusions based on statistics derived from 13F filings are generally supported by trading data. To be clear, we cannot identify the fund so we cannot characterize a fund as "short-term" or "long-term" and directly link the statistics used by other authors to holding periods. But our finding that trades held up to nine months are not generally based on information is consistent with papers arguing that short-term institutional trades do not reflect fundamental information. 


\section{REFERENCES}

Amihud, Y. "Illiquidity and Stock Returns: Cross Section and Time-series Effects." Journal of Financial Markets, 5 (2002), 31-56.

Anand, A.; P. Irvine; A. Puckett; and K. Venkataraman. "Institutional Trading and Stock Resiliency: Evidence from the 2007-2009 Financial Crisis." Journal of Financial Economics, 108 (2013), 773-797.

Asness, C. S.; T. J. Moskowitz; and L. H. Pedersen. "Value and Momentum Everywhere." Journal of Finance, 68 (2013), 929-985.

Ben-David, I., and D. Hirshleifer. “ Are Investors Really Reluctant to Realize Their Losses?

Trading Responses to Past Returns and the Disposition Effect." Review of Financial Studies, 25 (2012), 2485-2532.

Berk, J. B., and J. H. van Binsbergen. "Measuring Skill in the Mutual Fund Industry." Journal of Financial Economics, 118 (2015), 1-20.

Boehmer, E., and E. Kelley. "Institutional Investors and the Informational Efficiency of Prices." Review of Financial Studies, 22 (2009), 3563-3594.

Bushee, B. J. ”Do Institutional Investors Prefer Near-term Earnings over Long-run Value?" Contemporary Accounting Research, 18 (2001), 207-246.

Bushee, B. J., and C. F. Noe. "Corporate Disclosure Practices, Institutional Investors, and Stock Return Volatility.” Journal of Accounting Research, 38 (2000), 171-202.

Busse, J.; A. Goyal; and S. Wahal. "Performance and Persistence in Institutional Investment Management." Journal of Finance, 65 (2010), 765-790.

Cella, C.; A. Ellul; and M. Giannetti. "Investors' Horizons and the Amplification of Market Shocks." Review of Financial Studies, 26 (2013), 1607-1648.

Chaudhuri, R.; Z. Ivkovic; and C. Trzcinka. "Strategic Performance Allocation in Institutional Asset Management Firms: Behold the Power of Stars and Dominant Clients." Working paper (2014).

Chordia, T.; R. Roll; and A. Subrahmanyam. "Recent Trends in Trading Activity and Market Quality.” Journal of Financial Economics, 101 (2011), 243-263.

Chung, K. H., and H. Zhang. "Corporate Governance and Institutional Ownership." Journal of Financial and Quantitative Analysis, 46 (2011), 247-273. 
Coval, J., and T. Moskowitz. "Home Bias at Home: Local Equity Preference in Domestic Portfolios.” Journal of Finance, 54 (1999), 2045-2073.

Cremers, M., and A. Pareek. "Patient Capital Outperformance: The Investment Skill of High Active Share Managers Who Trade Infrequently.” Journal of Financial Economics, forthcoming (2015).

Cremers, M.; A. Pareek; and Zacharias Sautner. "Stock Duration, Analyst Recommendations, and Misevaluation." Working paper (2014).

Daniel, K.; M. Grinblatt; S. Titman; and R. Wermers. "Measuring Mutual Fund Performance with Characteristic-based Benchmarks.” Journal of Finance, 52 (1997), 1035-1058.

Dow, J., and G. Gorton. "Noise Trading, Delegated Portfolio Management, and Economic Welfare.” Journal of Political Economy, 105 (1997), 1024-1050.

Fama, E., and K. French. "Luck versus Skill in the Cross Section of Mutual Fund $\alpha$ Estimates." Journal of Finance, 65 (2010), 1915-1947.

Ferreira, M., and P. Matos. “The Colors of Investors' Money: The Role of Institutional Investors Around the World.” Journal of Financial Economics, 88 (2008), 499-533.

Fong, K.; C. W. Holden; and C. A. Trzcinka. "What are the Best Liquidity Proxies for Gobal Research?” Working paper (2014).

Frazzini, A. "The Disposition Effect and Underreaction to News.” Journal of Finance, 61 (2005), 2017-2046.

Gaspar, J.; M. Massa; and P. Matos. "Shareholder Investment Horizons and the Market for Corporate Control.” Journal of Financial Economics, 76 (2005), 135-165.

Gervais, S., and T. Odean. "Learning to be Overconfident." Review of Financial Studies, 14 (2001), 1-27.

Goldstein, M. A.; P. Irvine; E. Kandel; and Z. Wiener. "Brokerage Commissions and Institutional Trading Patterns.” Review of Financial Studies, 22 (2009), 5175-5212.

Griffin, J. M.; T. Shu; and S. Topaloglu. "Examining the Dark Side of Financial Markets: Do Institutions Trade on Information from Investment Bank Connections?” Review of Financial Studies, 25 (2012), 2155-2188.

Hu, G.; R. D. McLean; J. Pontiff; and Q. Wang. "The Year-end Trading Activities of Institutional Investors: Evidence from Daily Trades." Review of Financial Studies, 27 (2014), 3133-3170. 
Hvidkjaer, S. "Small Trades and the Cross-section of Stock Returns." Review of Financial Studies, 21 (2008), 1123-1151.

Investment Management Association. "Understanding Equity Turnover Data: Initial Findings from IMA Research Submitted to the Kay Review." (2011), 1-8.

Kosowski, R.; A. Timmerman; R. Wermers; and H. White. "Can Mutual Fund "Stars" Really Pick Stocks? New Evidence from a Bootstrap Analysis.” Journal of Finance, 61 (2006), 2551-2595.

Lakonishok, J.; A. Shleifer; and R. Vishny. "The Structure and Performance of the Money Management Industry.” Brookings Papers: Microeconomics (1992), 339-391.

Lewellen, J. “Institutional Investors and the Limits of Arbitrage." Journal of Financial Economics, 102 (2011), 62-80.

Ma, L.; Y. Tang; and J. Gomez. "Portfolio Manager Compensation in the U.S. Mutual Fund Industry." Working paper (2015).

Moore, D. A., and J. Healy. "The Trouble with Overconfidence.” Psychological Review, 115 (2008), 502-517.

Nofsinger, J., and A. Varma. "Availability, Recency and Sophistication in the Repurchasing Behavior of Retail Investors." Journal of Banking and Finance, 37 (2013), 2572-2585.

Puckett, A., and X. Yan. "The Interim Trading Skills of Institutional Investors." Journal of Finance, 66 (2011), 601-633.

Shefrin, H. "Behavioral Finance: Biases, Mean-variance Returns, and Risk Premiums." CFA Institute Conference Proceedings Quarterly, 31 (2007), 4-12.

Shefrin, H., and M. Statman. "The Disposition to Sell Winners Too Early and Ride Losers Too Long: Theory and Evidence.” Journal of Finance, 40 (1985), 777-791.

Tversky, A., and D. Kahneman. "Availability: A Heuristic for Judging Frequency and Probability." Cognitive Psychology, 5 (1973), 207-232.

U.S. Department of Labor. "Cross-trades of Securities by Investment Managers." Federal Register Notice, 63 (1998), 13696-13701.

Wang, Z. J., and V. Nanda. "Payout Policies and Closed-end Fund Discounts: Signaling, Agency Costs, and the Role of Institutional Investors." Journal of Financial Intermediation 20 (2011), 589-619. 
Table 1: Sample descriptive statistics

Institutional trading data are from Ancerno Ltd. for trades executed between January 1, 1999, and December 31, 2009. The table presents statistics for all FIFO round-trip trades in common stocks for the entire universe of pension and money manger funds reporting to Ancerno (Full Sample) and the subset of funds that are present in the Ancerno database for five or more years (Funds present 5 or more years ). Panel A presents descriptive statistics for the two samples, and Panel B presents the distribution of round-trip trades for each sample by stock market capitalization decile. Market capitalization deciles are determined from CRSP, based on the market capitalization of each stock at the end of the year prior to the initiation of the trade.

Panel A: Funds, institutions, and round-trip trades

\begin{tabular}{lcc}
\hline & & Funds present 5 or more \\
& Full Sample & years \\
\hline Number of funds & 4,053 & 1,186 \\
Pension funds & 3,811 & 1,102 \\
Money managers & 242 & 84 \\
Number of institutions & 772 & 324 \\
Median number of funds per institution & 3 & 3 \\
Total share volume of round-trip trades (billion) & 328.41 & 291.13 \\
Pension funds & 30.07 & 18.83 \\
Money managers & 298.34 & 272.30 \\
Total dollar volume of round-trip trades (\$ trillion) & 10.08 & 8.94 \\
Pension funds & 0.91 & 0.55 \\
Money managers & 9.17 & 8.39 \\
Total number of round-trip trades (million) & 121.03 & 105.59 \\
Pension funds & 9.51 & 6.25 \\
Money managers & 111.52 & 99.33 \\
Total number of stocks traded & 9,737 & 9,407 \\
\hline
\end{tabular}

Panel B: Distribution of round-trip trades by stock market capitalization decile

\begin{tabular}{|c|c|c|c|c|c|c|}
\hline \multirow[b]{2}{*}{ Decile } & \multicolumn{3}{|c|}{ Full Sample } & \multicolumn{3}{|c|}{ Funds present 5 or more years } \\
\hline & $\begin{array}{l}\% \text { Share } \\
\text { Volume }\end{array}$ & $\begin{array}{c}\text { \% Dollar } \\
\text { Volume }\end{array}$ & $\%$ Trades & $\begin{array}{l}\% \text { Share } \\
\text { Volume }\end{array}$ & $\begin{array}{c}\text { \% Dollar } \\
\text { Volume }\end{array}$ & $\%$ Trades \\
\hline D1 (Smallest) & 0.03 & 0.02 & 0.04 & 0.03 & 0.01 & 0.03 \\
\hline D2 & 0.11 & 0.03 & 0.13 & 0.11 & 0.02 & 0.09 \\
\hline D3 & 0.26 & 0.08 & 0.28 & 0.26 & 0.07 & 0.23 \\
\hline D4 & 0.62 & 0.19 & 0.75 & 0.62 & 0.19 & 0.68 \\
\hline D5 & 1.25 & 0.50 & 1.64 & 1.25 & 0.50 & 1.56 \\
\hline D6 & 2.23 & 1.03 & 3.02 & 2.21 & 1.01 & 2.89 \\
\hline D7 & 4.05 & 2.24 & 5.30 & 4.01 & 2.21 & 5.06 \\
\hline D8 & 7.36 & 4.88 & 8.92 & 7.29 & 4.84 & 8.61 \\
\hline D9 & 15.21 & 11.97 & 14.96 & 15.14 & 11.86 & 14.48 \\
\hline D10 (Largest) & 68.88 & 79.06 & 64.96 & 69.09 & 79.27 & 66.36 \\
\hline Total & 100.00 & 100.00 & 100.00 & 100.00 & 100.00 & 100.00 \\
\hline
\end{tabular}




\section{Table 2: Round-trip trades by holding period}

Institutional trading data are from Ancerno Ltd. for trades executed between January 1, 1999, and December 31, 2009 by funds in the database for five or more years. Panel A presents statistics based on round-trip trades defined using FIFO methodology; Panel B presents statistics based on round-trip trades defined using LIFO methodology. Holding period refers to the time between when a trade is initiated and when it is unwound. The columns labeled Aggregate Shares present percentages calculated across all round-trip trades in each category; the columns labeled Fund-level Cumulative Percentages present statistics about the cumulative percentages of share volume in trades with holding periods less than or equal to the period specified, across the funds in each sample.

\section{Panel A: FIFO round-trip trades}

\begin{tabular}{|c|c|c|c|c|c|c|c|}
\hline & & & & \multicolumn{4}{|c|}{ Fund-level Cumulative Percentages (\%) } \\
\hline \multicolumn{2}{|c|}{ Holding Period } & \multicolumn{2}{|c|}{ Aggregate Shares } & \multicolumn{2}{|c|}{ Money Manager } & \multicolumn{2}{|c|}{ Pension } \\
\hline At least & Less than & $\%$ & Cumulative \% & Mean & Median & Mean & Median \\
\hline 1 day & 1 week & 1.38 & 1.38 & 1.37 & 0.98 & 1.30 & 0.26 \\
\hline 1 week & 1 month & 5.80 & 7.18 & 7.23 & 6.05 & 5.18 & 3.42 \\
\hline 1 month & 2 months & 8.00 & 15.18 & 15.25 & 14.35 & 11.73 & 9.45 \\
\hline 2 months & 3 months & 7.87 & 23.06 & 23.13 & 23.11 & 18.48 & 16.09 \\
\hline 3 months & 4 months & 7.49 & 30.54 & 30.36 & 29.88 & 25.07 & 23.05 \\
\hline 4 months & 5 months & 6.82 & 37.37 & 36.92 & 36.75 & 31.12 & 29.81 \\
\hline 5 months & 6 months & 6.02 & 43.39 & 42.82 & 42.71 & 36.58 & 36.23 \\
\hline 6 months & 9 months & 14.80 & 58.18 & 57.15 & 58.39 & 50.57 & 52.25 \\
\hline 9 months & 1 year & 10.59 & 68.77 & 67.67 & 70.20 & 61.28 & 64.35 \\
\hline 1 year & 2 years & 19.77 & 88.54 & 88.93 & 90.61 & 84.30 & 88.99 \\
\hline 2 years & 3 years & 6.74 & 95.28 & 95.98 & 97.03 & 93.28 & 96.61 \\
\hline 3 years & 4 years & 2.64 & 97.92 & 98.40 & 99.18 & 97.09 & 99.23 \\
\hline 4 years & & 2.08 & 100.00 & 100.00 & 100.00 & 100.00 & 100.00 \\
\hline
\end{tabular}

Panel B: LIFO round-trip trades

\begin{tabular}{|c|c|c|c|c|c|c|c|}
\hline & & & & \multicolumn{4}{|c|}{ Fund-level Cumulative Percentages (\%) } \\
\hline \multicolumn{2}{|c|}{ Holding Period } & \multicolumn{2}{|c|}{ Aggregate Shares } & \multicolumn{2}{|c|}{ Money Manager } & \multicolumn{2}{|c|}{ Pension } \\
\hline At least & Less than & $\%$ & Cumulative \% & Mean & Median & Mean & Median \\
\hline 1 day & 1 week & 11.83 & 11.83 & 6.86 & 5.62 & 1.98 & 0.72 \\
\hline 1 week & 1 month & 16.06 & 27.90 & 20.16 & 18.24 & 8.42 & 6.23 \\
\hline 1 month & 2 months & 11.89 & 39.79 & 31.74 & 30.89 & 17.39 & 14.94 \\
\hline 2 months & 3 months & 8.42 & 48.20 & 40.63 & 41.18 & 25.52 & 23.67 \\
\hline 3 months & 4 months & 6.55 & 54.76 & 47.70 & 48.48 & 32.81 & 31.81 \\
\hline 4 months & 5 months & 5.32 & 60.08 & 53.70 & 54.99 & 39.09 & 39.26 \\
\hline 5 months & 6 months & 4.39 & 64.47 & 58.53 & 60.84 & 44.61 & 45.18 \\
\hline 6 months & 9 months & 9.59 & 74.06 & 69.49 & 72.29 & 57.86 & 60.92 \\
\hline 9 months & 1 year & 6.45 & 80.50 & 77.26 & 79.59 & 67.51 & 71.75 \\
\hline 1 year & 2 years & 11.91 & 92.41 & 91.98 & 92.97 & 86.92 & 90.76 \\
\hline 2 years & 3 years & 4.21 & 96.62 & 96.78 & 97.28 & 94.20 & 96.90 \\
\hline 3 years & 4 years & 1.83 & 98.45 & 98.66 & 99.26 & 97.47 & 99.20 \\
\hline 4 years & & 1.55 & 100.00 & 100.00 & 100.00 & 100.00 & 100.00 \\
\hline
\end{tabular}


Table 3: Trade returns by holding period

Institutional trading data are from Ancerno Ltd. for trades executed between January 1, 1999, and December 31, 2009 by funds in the database for five or more years. The table reports FIFO round-trip trade average returns that are weighted by principal amount (initial share price times number of shares) within each holding period category. Raw return (Panel A) is the percentage price change over the holding period; and DGTW-adjusted return (Panel B) subtracts the DGTW benchmark return over the identical holding period from the raw return for each round-trip trade. Means and medians in bold are significantly different from zero with a $p$-value less than 0.01 ; means and medians in italics are significantly different from zero with a $p$-value less than 0.05 .

Panel A: Raw returns

\begin{tabular}{|c|c|c|c|c|c|c|c|c|c|c|}
\hline \multirow{2}{*}{\multicolumn{2}{|c|}{ Holding Period }} & \multirow{3}{*}{$\begin{array}{l}\text { Aggregate } \\
\text { Trade } \\
\text { Returns } \\
\end{array}$} & \multicolumn{8}{|c|}{ Fund-level Trade Returns } \\
\hline & & & \multicolumn{4}{|c|}{ Money Managers } & \multicolumn{4}{|c|}{ Pension Funds } \\
\hline At least & Less than & & Mean & Median & 25th P'tile & 75th P'tile & Mean & Median & 25th P'tile & 75th P'tile \\
\hline 1 day & 1 week & -1.00 & -0.82 & -0.54 & -1.51 & 0.36 & -1.52 & -0.54 & -4.14 & 1.94 \\
\hline 1 week & 1 month & -2.72 & -2.06 & -1.56 & -3.81 & -0.44 & -3.14 & -2.48 & -7.46 & 1.29 \\
\hline 1 month & 2 months & -3.99 & -0.80 & -2.36 & -5.18 & 0.58 & -3.07 & -2.59 & -7.65 & 2.15 \\
\hline 2 months & 3 months & -5.22 & -2.64 & -2.94 & -6.59 & 0.41 & -3.37 & -3.41 & -8.82 & 2.13 \\
\hline 3 months & 4 months & -4.88 & -3.24 & -3.37 & -6.95 & -0.27 & -3.12 & -2.82 & -8.86 & 2.76 \\
\hline 4 months & 5 months & -5.07 & -2.85 & -3.75 & -6.56 & 0.13 & -2.93 & -2.85 & -9.60 & 3.40 \\
\hline 5 months & 6 months & -5.32 & -2.87 & -3.30 & -7.50 & 0.13 & -2.35 & -2.37 & -9.60 & 4.35 \\
\hline 6 months & 9 months & -4.79 & -1.89 & -1.94 & -7.51 & 1.69 & -2.11 & -1.48 & -8.52 & 4.59 \\
\hline 9 months & 1 year & -4.36 & -2.10 & -1.07 & -7.89 & 3.20 & -0.97 & -0.56 & -8.71 & 6.81 \\
\hline 1 year & 2 years & -2.31 & 0.14 & 0.41 & -6.66 & 7.53 & 1.27 & 1.79 & -7.80 & 11.07 \\
\hline 2 years & 3 years & 1.46 & 3.66 & 5.36 & -7.35 & 14.12 & 3.19 & 4.73 & -9.63 & 18.42 \\
\hline 3 years & 4 years & 6.71 & 5.93 & 10.31 & -6.62 & 24.23 & 4.06 & 6.87 & -12.63 & 24.84 \\
\hline 4 years & & 11.11 & 3.18 & 4.59 & -13.92 & 22.10 & 6.76 & 10.03 & -12.81 & 31.02 \\
\hline
\end{tabular}

Panel B: DGTW-adjusted returns

\begin{tabular}{|c|c|c|c|c|c|c|c|c|c|c|}
\hline \multirow{2}{*}{\multicolumn{2}{|c|}{ Holding Period }} & \multirow{3}{*}{$\begin{array}{l}\text { Aggregate } \\
\text { Trade } \\
\text { Returns } \\
\end{array}$} & \multicolumn{8}{|c|}{ Fund-level Trade Returns } \\
\hline & & & \multicolumn{4}{|c|}{ Money Managers } & \multicolumn{4}{|c|}{ Pension Funds } \\
\hline At least & Less than & & Mean & Median & 25th P'tile & 75th P'tile & Mean & Median & 25th P'tile ? & 75th P'tile \\
\hline 1 day & 1 week & -0.56 & -0.57 & -0.37 & -1.90 & 0.28 & -1.47 & -0.51 & -3.71 & 1.30 \\
\hline 1 week & 1 month & -0.99 & -1.40 & -0.89 & -3.46 & 0.02 & -2.30 & -1.56 & -5.61 & 1.18 \\
\hline 1 month & 2 months & -1.28 & -1.21 & -1.20 & -4.44 & 0.22 & -2.17 & -1.79 & -5.55 & 1.30 \\
\hline 2 months & 3 months & -1.49 & -0.74 & -1.12 & -4.95 & 0.36 & -2.25 & -2.35 & -6.24 & 1.58 \\
\hline 3 months & 4 months & -0.96 & -1.07 & -1.07 & -4.94 & 1.04 & -2.48 & -2.47 & -7.06 & 1.83 \\
\hline 4 months & 5 months & -0.79 & -0.98 & -1.67 & -3.85 & 0.71 & -1.89 & -2.22 & -6.85 & 1.94 \\
\hline 5 months & 6 months & -0.73 & -0.74 & -0.61 & -4.51 & 1.32 & -1.69 & -2.15 & -6.96 & 2.69 \\
\hline 6 months & 9 months & 0.26 & -0.31 & -0.02 & -4.35 & 1.83 & -1.64 & -1.25 & -5.86 & 2.46 \\
\hline 9 months & 1 year & 1.19 & -0.40 & 0.30 & -4.76 & 2.74 & 0.10 & 0.00 & -4.81 & 4.47 \\
\hline 1 year & 2 years & 2.88 & 2.24 & 2.66 & -1.72 & 5.41 & 1.11 & 1.31 & -4.25 & 5.93 \\
\hline 2 years & 3 years & 2.54 & 4.00 & 4.40 & -4.82 & 10.12 & 3.62 & 3.22 & -4.26 & 10.91 \\
\hline 3 years & 4 years & 3.65 & 4.67 & 6.31 & -7.22 & 14.68 & 6.33 & 3.42 & -9.60 & 16.43 \\
\hline 4 years & & 7.78 & 8.79 & 6.62 & -17.23 & 16.51 & 4.68 & 2.64 & -13.26 & 16.47 \\
\hline
\end{tabular}


Table 4: Short-duration trade returns by stock, market, and fund characteristics

Institutional trading data are from Ancerno Ltd. for trades executed between January 1, 1999, and December 31, 2009 by funds in the database for five or more years. Analysis is run separately for money manager funds and for pension funds, and short-term trades are defined as FIFO round-trip trades held for less than three months. In the first five columns of Panel A, short-term trades are sorted by stock characteristics, with quintile rankings determined annually across all stocks with short-term trades in that year. In the last column of Panel A short-term trades are sorted into quintiles based on the volatility of the S\&P 500 index in the month the trade is closed out. In Panel B, funds are sorted into quintiles based on their average annual percentage of short-term trades (first two columns), average annual dollar volume of round-trip trades (middle two columns), and average size of short-term trades (last two columns). DGTW-adjusted average returns for each fund's short-term trades are weighted across trades by principal amount (initial share price times number of shares).Numbers in parentheses are $t$-statistics, which are computed based on double-clustered standard errors in Panel A.

Panel A: Sorts by stock and market characteristics

\begin{tabular}{|c|c|c|c|c|c|c|}
\hline Quintile & Beta & Size & $\begin{array}{l}\text { Amihud } \\
\text { Illiquidity }\end{array}$ & $\begin{array}{l}\text { Book/ } \\
\text { Market }\end{array}$ & $\begin{array}{c}\text { Mo- } \\
\text { mentum }\end{array}$ & $\begin{array}{c}\text { Market } \\
\text { Volatility }\end{array}$ \\
\hline \multirow[t]{2}{*}{ Q1 } & 0.02 & -6.71 & -1.45 & 0.26 & -6.25 & -0.53 \\
\hline & $(0.0)$ & $(-3.5)$ & $(-2.2)$ & $(0.4)$ & $(-3.6)$ & $(-2.0)$ \\
\hline \multirow[t]{2}{*}{ Q2 } & -1.08 & -3.19 & -0.28 & -0.07 & -1.89 & -0.73 \\
\hline & $(-2.1)$ & $(-3.9)$ & $(-0.7)$ & $(-0.2)$ & $(-2.2)$ & $(-1.2)$ \\
\hline \multirow[t]{2}{*}{ Q3 } & -0.39 & -1.26 & -1.33 & -1.46 & -0.58 & -1.45 \\
\hline & $(-1.4)$ & $(-2.9)$ & $(-4.0)$ & $(-2.4)$ & $(-1.9)$ & $(-1.5)$ \\
\hline \multirow[t]{2}{*}{ Q4 } & -1.71 & -0.80 & -2.47 & -3.08 & -0.17 & -1.10 \\
\hline & $(-2.0)$ & $(-1.5)$ & $(-2.4)$ & $(-4.4)$ & $(-0.5)$ & $(-1.3)$ \\
\hline \multirow[t]{2}{*}{ Q5 } & -2.19 & -1.15 & -0.10 & -7.06 & 0.87 & -2.24 \\
\hline & $(-1.7)$ & $(-1.8)$ & $(-0.1)$ & $(-3.3)$ & (1.1) & $(-2.7)$ \\
\hline \multirow[t]{2}{*}{ Q5-Q1 } & -2.21 & 5.56 & 1.35 & -7.33 & 7.12 & -1.71 \\
\hline & $(-1.1)$ & (3.6) & (2.3) & $(-4.0)$ & (4.1) & $(-2.0)$ \\
\hline
\end{tabular}

Panel B: Sorts by fund characteristics

\begin{tabular}{|c|c|c|c|c|c|c|}
\hline \multirow[b]{2}{*}{ Quintile } & \multicolumn{2}{|c|}{ \% Short-term trades } & \multicolumn{2}{|c|}{ Amount of trading } & \multicolumn{2}{|c|}{ Average trade size } \\
\hline & $\begin{array}{c}\text { Money } \\
\text { Managers }\end{array}$ & $\begin{array}{c}\text { Pension } \\
\text { Funds }\end{array}$ & $\begin{array}{c}\text { Money } \\
\text { Managers }\end{array}$ & $\begin{array}{c}\text { Pension } \\
\text { Funds }\end{array}$ & $\begin{array}{c}\text { Money } \\
\text { Managers }\end{array}$ & $\begin{array}{c}\text { Pension } \\
\text { Funds }\end{array}$ \\
\hline \multirow[t]{2}{*}{ Q1 } & -1.18 & -0.16 & -0.29 & -1.40 & 1.11 & -1.07 \\
\hline & $(-1.7)$ & $(-0.2)$ & $(-0.2)$ & $(-1.5)$ & $(0.7)$ & $(-1.6)$ \\
\hline \multirow[t]{2}{*}{ Q2 } & 0.65 & -1.47 & -0.27 & -1.81 & -0.78 & -2.30 \\
\hline & (0.4) & $(-2.5)$ & $(-0.3)$ & $(-3.5)$ & $(-1.5)$ & $(-4.3)$ \\
\hline \multirow[t]{2}{*}{ Q3 } & -1.77 & -2.26 & -1.35 & -1.77 & -2.11 & -2.49 \\
\hline & $(-2.1)$ & $(-4.9)$ & $(-2.1)$ & $(-3.6)$ & $(-3.3)$ & $(-5.3)$ \\
\hline \multirow[t]{2}{*}{ Q4 } & -1.17 & -2.89 & -1.61 & -2.32 & -1.37 & -1.81 \\
\hline & $(-3.7)$ & $(-7.4)$ & $(-4.9)$ & $(-6.0)$ & $(-2.6)$ & $(-3.5)$ \\
\hline \multirow[t]{2}{*}{ Q5 } & -1.38 & -3.51 & -1.28 & -3.06 & -1.57 & -2.73 \\
\hline & $(-2.8)$ & $(-7.9)$ & $(-2.7)$ & $(-8.9)$ & $(-2.4)$ & $(-4.8)$ \\
\hline \multirow[t]{2}{*}{ Q5-Q1 } & -0.20 & -3.36 & -0.99 & -1.66 & -2.68 & -1.66 \\
\hline & $(-0.2)$ & $(-3.8)$ & $(-0.6)$ & $(-1.8)$ & $(-1.6)$ & $(-1.9)$ \\
\hline
\end{tabular}


Table 5: Short-duration trade return persistence at the fund level

Institutional trading data are from Ancerno Ltd. for trades executed between January 1, 1999, and December 31, 2009 by funds in the database for five or more years. Analysis is run for separately for money manager funds and for pension funds. In each panel, funds are sorted into quintiles based on the average returns on their under-threemonth FIFO round-trip trades in each semiannual period, and the average fund returns (in \%) for each quintile are reported in the quintile formation period (Base period) and the subsequent four semiannual periods (Base +1 , Base+2, Base+3, and Base+4). DGTW-adjusted average returns for each fund's under-three-month round-trip trades are weighted across trades by principal amount (initial share price times number of shares). Numbers in parentheses are $t$-statistics, which are computed based on double-clustered standard errors.

Panel A: Money Managers

\begin{tabular}{|c|c|c|c|c|c|}
\hline \multirow[b]{2}{*}{ Quintile } & \multicolumn{5}{|c|}{ Semiannual periods } \\
\hline & Base period & Base +1 & Base +2 & Base +3 & Base +4 \\
\hline Q1 & $\begin{array}{l}-15.96 \\
(-10.3)\end{array}$ & $\begin{array}{l}-2.86 \\
(-2.5)\end{array}$ & $\begin{array}{l}-3.74 \\
(-2.2)\end{array}$ & $\begin{array}{l}-0.28 \\
(-0.2)\end{array}$ & $\begin{array}{l}-1.65 \\
(-0.9)\end{array}$ \\
\hline Q2 & $\begin{array}{l}-5.07 \\
(-8.6)\end{array}$ & $\begin{array}{l}-1.65 \\
(-2.4)\end{array}$ & $\begin{array}{l}-1.64 \\
(-1.4)\end{array}$ & $\begin{array}{l}-1.84 \\
(-2.8)\end{array}$ & $\begin{array}{l}-0.57 \\
(-0.6)\end{array}$ \\
\hline Q3 & $\begin{array}{l}-1.58 \\
(-4.4)\end{array}$ & $\begin{array}{l}-0.99 \\
(-1.9)\end{array}$ & $\begin{array}{l}-1.13 \\
(-2.4)\end{array}$ & $\begin{array}{l}-1.68 \\
(-2.6)\end{array}$ & $\begin{array}{l}-0.97 \\
(-1.9)\end{array}$ \\
\hline Q4 & $\begin{array}{l}1.56 \\
(3.6)\end{array}$ & $\begin{array}{l}-0.11 \\
(-0.3)\end{array}$ & $\begin{array}{l}-0.86 \\
(-1.5)\end{array}$ & $\begin{array}{l}-0.41 \\
(-0.7)\end{array}$ & $\begin{array}{l}-1.09 \\
(-1.5)\end{array}$ \\
\hline Q5 & $\begin{array}{c}9.78 \\
(11.6)\end{array}$ & $\begin{array}{l}0.39 \\
(0.3)\end{array}$ & $\begin{array}{l}1.96 \\
(2.1)\end{array}$ & $\begin{array}{c}0.78 \\
(0.8)\end{array}$ & $\begin{array}{l}0.02 \\
(0.0)\end{array}$ \\
\hline Q5-Q1 & $\begin{array}{l}25.74 \\
(13.2)\end{array}$ & $\begin{array}{l}3.25 \\
(2.1)\end{array}$ & $\begin{array}{l}5.70 \\
(2.8)\end{array}$ & $\begin{array}{l}1.06 \\
(0.5)\end{array}$ & $\begin{array}{l}1.68 \\
(0.8)\end{array}$ \\
\hline
\end{tabular}

Panel B: Pension Funds

\begin{tabular}{|c|c|c|c|c|c|}
\hline \multirow[b]{2}{*}{ Quintile } & \multicolumn{5}{|c|}{ Semiannual periods } \\
\hline & Base period & Base +1 & Base +2 & Base +3 & Base +4 \\
\hline Q1 & $\begin{array}{l}-18.81 \\
(-13.7)\end{array}$ & $\begin{array}{l}-4.99 \\
(-6.9)\end{array}$ & $\begin{array}{l}-5.18 \\
(-6.4)\end{array}$ & $\begin{array}{l}-5.02 \\
(-5.5)\end{array}$ & $\begin{array}{l}-4.14 \\
(-5.1)\end{array}$ \\
\hline Q2 & $\begin{array}{c}-6.11 \\
(-10.9)\end{array}$ & $\begin{array}{l}-3.15 \\
(-4.9)\end{array}$ & $\begin{array}{l}-3.44 \\
(-5.4)\end{array}$ & $\begin{array}{l}-3.48 \\
(-5.5)\end{array}$ & $\begin{array}{l}-3.52 \\
(-5.7)\end{array}$ \\
\hline Q3 & $\begin{array}{l}-1.92 \\
(-5.4)\end{array}$ & $\begin{array}{l}-3.06 \\
(-5.6)\end{array}$ & $\begin{array}{l}-2.20 \\
(-4.1)\end{array}$ & $\begin{array}{l}-2.39 \\
(-4.2)\end{array}$ & $\begin{array}{l}-2.62 \\
(-4.2)\end{array}$ \\
\hline Q4 & $\begin{array}{l}1.64 \\
(5.9)\end{array}$ & $\begin{array}{l}-1.46 \\
(-3.2)\end{array}$ & $\begin{array}{l}-1.41 \\
(-2.2)\end{array}$ & $\begin{array}{l}-1.97 \\
(-3.2)\end{array}$ & $\begin{array}{l}-2.05 \\
(-3.9)\end{array}$ \\
\hline Q5 & $\begin{array}{l}14.17 \\
(15.4)\end{array}$ & $\begin{array}{l}0.19 \\
(0.3)\end{array}$ & $\begin{array}{l}-1.03 \\
(-1.5)\end{array}$ & $\begin{array}{l}-0.35 \\
(-0.4)\end{array}$ & $\begin{array}{l}-0.38 \\
(-0.5)\end{array}$ \\
\hline Q5-Q1 & $\begin{array}{l}32.98 \\
(17.0)\end{array}$ & $\begin{array}{l}5.18 \\
(7.7)\end{array}$ & $\begin{array}{l}4.14 \\
(7.5)\end{array}$ & $\begin{array}{l}4.67 \\
(5.4)\end{array}$ & $\begin{array}{l}3.76 \\
(5.1)\end{array}$ \\
\hline
\end{tabular}


Table 6: Trade returns by holding period IF trades had been held for 1 year instead of less than $\mathbf{3}$ months

Institutional trading data are from Ancerno Ltd. for trades executed between January 1, 1999, and December 31, 2009 by funds in the database for five or more years. For each actual trade in the database that was held for less than three months under the FIFO method, we calculate the "what-if" one-year return as the return the trade would have earned if it had been held for the remainder of a full year instead of closed within three months (for example, the return that would have been earned if a one-week trade had been held for the subsequent 51 weeks). The table reports round-trip trade average "what-if" raw returns that are weighted by principal amount (initial share price times number of shares) within each holding period category. Raw return (Panel A) is the percentage price change over the holding period; DGTWadjusted return (Panel B) subtracts the DGTW benchmark return over the identical holding period from the raw return for each round-trip trade. Means and medians in bold are significantly different from zero with a $p$-value less than 0.01 ; means and medians in italics are significantly different from zero with a $p$-value less than 0.05 .

Panel A: Raw returns on trades held less than three months IF they had been held for one year

\begin{tabular}{|c|c|c|c|c|c|c|c|c|c|c|}
\hline \multirow{2}{*}{\multicolumn{2}{|c|}{$\begin{array}{c}\text { Actual } \\
\text { Holding Period }\end{array}$}} & \multirow{3}{*}{$\begin{array}{c}\text { Aggregate } \\
\text { 1-year "What-if" } \\
\text { Trade Returns }\end{array}$} & \multicolumn{8}{|c|}{ Fund-level 1-year "What-if" Trade Returns } \\
\hline & & & \multicolumn{4}{|c|}{ Money Managers } & \multicolumn{4}{|c|}{ Pension Funds } \\
\hline At least & Less than & & Mean & Median & 25th P'tile & 75th P'tile & Mean & Median & 25th P'tile & 5th P'tile \\
\hline 1 day & 1 week & 35.11 & 16.18 & 12.94 & 2.79 & 24.26 & 8.81 & 3.89 & -10.22 & 18.80 \\
\hline 1 week & 1 month & 33.76 & 33.29 & 11.55 & 6.01 & 23.60 & 16.34 & 6.65 & -2.55 & 18.49 \\
\hline 1 month & 2 months & 61.86 & 39.64 & 21.56 & 7.09 & 45.14 & 16.56 & 4.69 & -5.82 & 20.40 \\
\hline 2 months & 3 months & 37.30 & 19.13 & 8.96 & 1.38 & 24.01 & 22.51 & 4.06 & -5.27 & 19.00 \\
\hline
\end{tabular}

Panel B: DGTW-adjusted returns on trades held less than three months IF they had been held for one year

\begin{tabular}{|c|c|c|c|c|c|c|c|c|c|c|}
\hline \multirow{2}{*}{\multicolumn{2}{|c|}{$\begin{array}{c}\text { Actual } \\
\text { Holding Period } \\
\end{array}$}} & \multirow{3}{*}{$\begin{array}{c}\text { Aggregate } \\
\text { 1-year "What-if" } \\
\text { Trade Returns } \\
\end{array}$} & \multicolumn{8}{|c|}{ Fund-level 1-year "What-if" Trade Returns } \\
\hline & & & \multicolumn{4}{|c|}{ Money Managers } & \multicolumn{4}{|c|}{ Pension Funds } \\
\hline At least & Less than & & Mean & Median & 25th P'tile & 75th P'tile & Mean & Median & 25th P'tile & th P'tile \\
\hline 1 day & 1 week & 0.01 & -0.42 & -0.07 & -3.03 & 1.95 & 0.15 & -0.05 & -9.44 & 8.36 \\
\hline 1 week & 1 month & 0.70 & 0.05 & 0.45 & -1.38 & 2.70 & 1.84 & 0.91 & -3.86 & 6.11 \\
\hline 1 month & 2 months & 1.15 & 0.52 & 0.58 & -1.26 & 3.08 & 1.53 & 1.21 & -2.97 & 5.84 \\
\hline 2 months & 3 months & 3.39 & 1.59 & 0.78 & -1.10 & 4.34 & 2.02 & 0.98 & -2.82 & 5.60 \\
\hline
\end{tabular}


Table 7: Short-duration trading amount following returns

Institutional trading data are from Ancerno Ltd. for trades executed between January 1, 1999, and December 31, 2009 by funds in the database for five or more years. Analysis is run separately for money manager funds and for pension funds. In each panel, funds are sorted into quintiles based on the average DGTW-adjusted returns on under-three-month FIFO round-trip trades in each semiannual period, and the average percentages of share volume that occurs in short-duration trades (in \%) for each quintile are reported in the quintile formation period (Base period) and the subsequent four semiannual periods (Base+1, Base +2, Base +3 , and Base +4 ). Numbers in parentheses are $t$-statistics, which are computed based on double-clustered standard errors.

Panel A: Money Managers

\begin{tabular}{|c|c|c|c|c|c|}
\hline \multirow[b]{2}{*}{ Quintile } & \multicolumn{5}{|c|}{ Semiannual periods } \\
\hline & Base period & Base +1 & Base +2 & Base +3 & Base +4 \\
\hline Q1 & $\begin{array}{c}14.78 \\
(5.2)\end{array}$ & $\begin{array}{c}15.71 \\
(4.1)\end{array}$ & $\begin{array}{l}19.81 \\
(6.3)\end{array}$ & $\begin{array}{c}19.43 \\
(4.6)\end{array}$ & $\begin{array}{c}24.75 \\
(3.5)\end{array}$ \\
\hline Q2 & $\begin{array}{c}17.00 \\
(7.7)\end{array}$ & $\begin{array}{c}18.77 \\
(8.9)\end{array}$ & $\begin{array}{c}20.24 \\
(4.9)\end{array}$ & $\begin{array}{c}23.28 \\
(5.7)\end{array}$ & $\begin{array}{c}23.99 \\
(6.9)\end{array}$ \\
\hline Q3 & $\begin{array}{c}20.40 \\
(8.7)\end{array}$ & $\begin{array}{c}20.78 \\
(6.3)\end{array}$ & $\begin{array}{c}21.53 \\
(6.9)\end{array}$ & $\begin{array}{c}22.04 \\
(6.0)\end{array}$ & $\begin{array}{c}22.37 \\
(5.4)\end{array}$ \\
\hline Q4 & $\begin{array}{c}22.03 \\
(5.3)\end{array}$ & $\begin{array}{c}20.69 \\
(5.7)\end{array}$ & $\begin{array}{c}19.35 \\
(5.1)\end{array}$ & $\begin{array}{c}18.15 \\
(5.6)\end{array}$ & $\begin{array}{c}19.47 \\
(4.7)\end{array}$ \\
\hline Q5 & $\begin{array}{c}17.51 \\
(8.0)\end{array}$ & $\begin{array}{c}16.79 \\
(6.4) \\
\end{array}$ & $\begin{array}{c}15.75 \\
(5.5) \\
\end{array}$ & $\begin{array}{c}17.23 \\
(4.7) \\
\end{array}$ & $\begin{array}{c}17.07 \\
(6.2) \\
\end{array}$ \\
\hline Q5-Q1 & $\begin{array}{l}2.72 \\
(1.5)\end{array}$ & $\begin{array}{l}1.08 \\
(0.5)\end{array}$ & $\begin{array}{l}-4.06 \\
(-2.2)\end{array}$ & $\begin{array}{l}-2.20 \\
(-1.1)\end{array}$ & $\begin{array}{l}-7.68 \\
(-1.5)\end{array}$ \\
\hline
\end{tabular}

\section{Panel B: Pension Funds}

\begin{tabular}{|c|c|c|c|c|c|}
\hline \multirow[b]{2}{*}{ Quintile } & \multicolumn{5}{|c|}{ Semiannual periods } \\
\hline & Base period & Base +1 & Base +2 & Base +3 & Base +4 \\
\hline Q1 & $\begin{array}{l}16.33 \\
(11.8)\end{array}$ & $\begin{array}{l}18.45 \\
(10.8)\end{array}$ & $\begin{array}{l}19.61 \\
(12.3)\end{array}$ & $\begin{array}{l}19.86 \\
(10.9)\end{array}$ & $\begin{array}{l}20.49 \\
(10.4)\end{array}$ \\
\hline Q2 & $\begin{array}{l}20.08 \\
(14.4)\end{array}$ & $\begin{array}{l}20.28 \\
(12.8)\end{array}$ & $\begin{array}{l}21.09 \\
(13.1)\end{array}$ & $\begin{array}{l}22.09 \\
(13.3)\end{array}$ & $\begin{array}{l}23.18 \\
(12.0)\end{array}$ \\
\hline Q3 & $\begin{array}{l}21.90 \\
(15.1)\end{array}$ & $\begin{array}{l}20.59 \\
(14.5)\end{array}$ & $\begin{array}{l}20.86 \\
(13.2)\end{array}$ & $\begin{array}{l}21.45 \\
(12.2)\end{array}$ & $\begin{array}{l}22.03 \\
(13.0)\end{array}$ \\
\hline Q4 & $\begin{array}{l}20.84 \\
(14.5)\end{array}$ & $\begin{array}{l}19.50 \\
(13.8)\end{array}$ & $\begin{array}{l}20.59 \\
(11.4)\end{array}$ & $\begin{array}{l}20.79 \\
(11.3)\end{array}$ & $\begin{array}{l}23.43 \\
(10.6)\end{array}$ \\
\hline Q5 & $\begin{array}{c}15.68 \\
(9.3)\end{array}$ & $\begin{array}{l}17.51 \\
(11.1)\end{array}$ & $\begin{array}{c}17.50 \\
(9.8)\end{array}$ & $\begin{array}{c}19.35 \\
(8.8)\end{array}$ & $\begin{array}{c}19.82 \\
(9.8)\end{array}$ \\
\hline Q5-Q1 & $\begin{array}{l}-0.65 \\
(-0.7) \\
\end{array}$ & $\begin{array}{l}-0.94 \\
(-1.1) \\
\end{array}$ & $\begin{array}{l}-2.10 \\
(-2.6)\end{array}$ & $\begin{array}{l}-0.51 \\
(-0.4) \\
\end{array}$ & $\begin{array}{l}-0.68 \\
(-0.7)\end{array}$ \\
\hline
\end{tabular}


Figure 1: Proportion of short-duration trades by fund

Institutional trading data are from Ancerno Ltd. for trades executed between January 1, 1999, and December 31, 2009 by funds in the database for five or more years. The first two graphs present the percentages of round-trip trading volume of each fund that occurs in trades held for less than one month under the FIFO and LIFO methods for identifying round-trip trades. For example, in the first graph the fifth bar shows that for 104 funds in the database, trades held less than one month account for between 10\% and 20\% of their total trading volume. The last two graphs present the percentages of round-trip trading volume for each fund that occurs in trades held for less than three months.
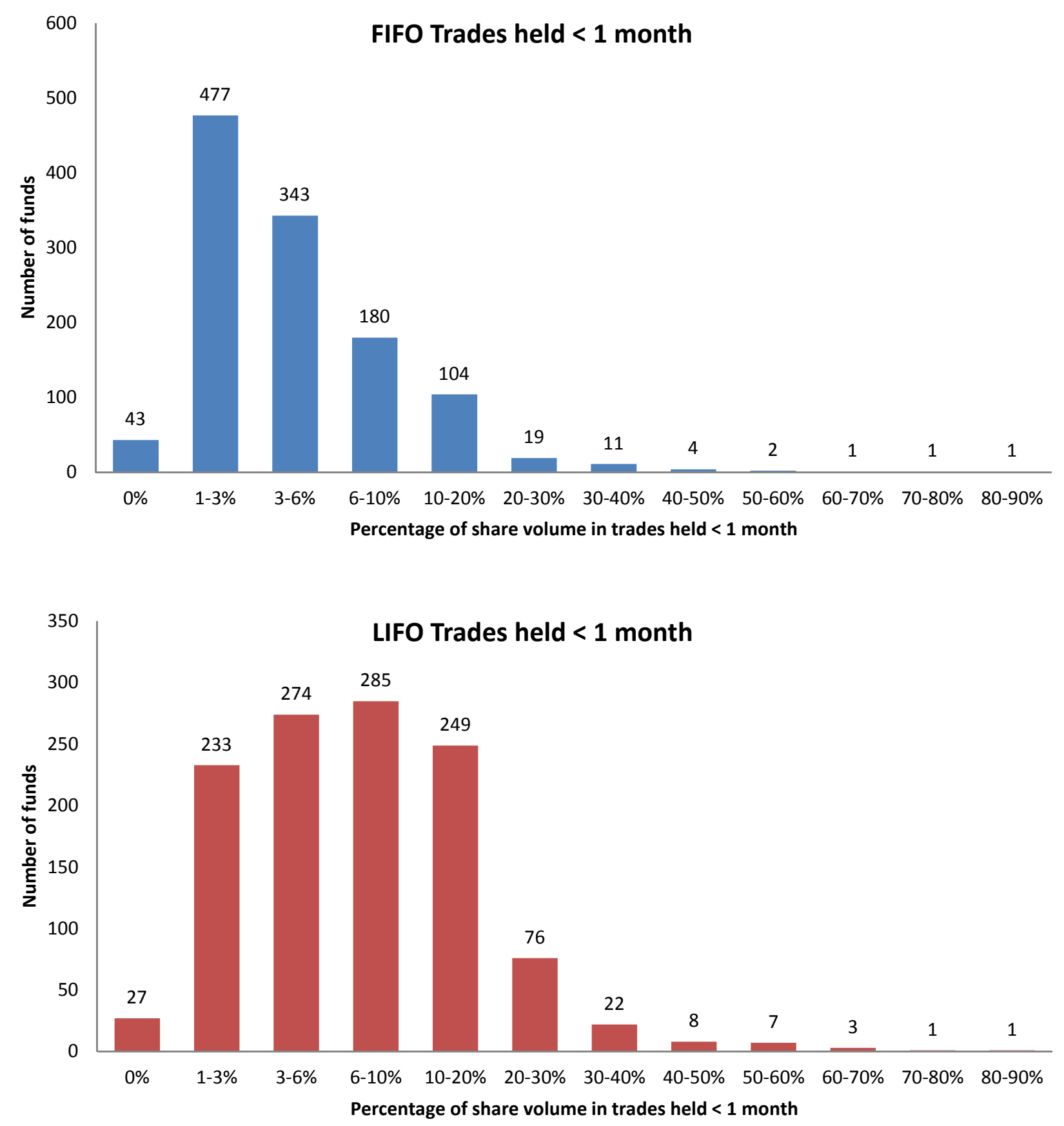


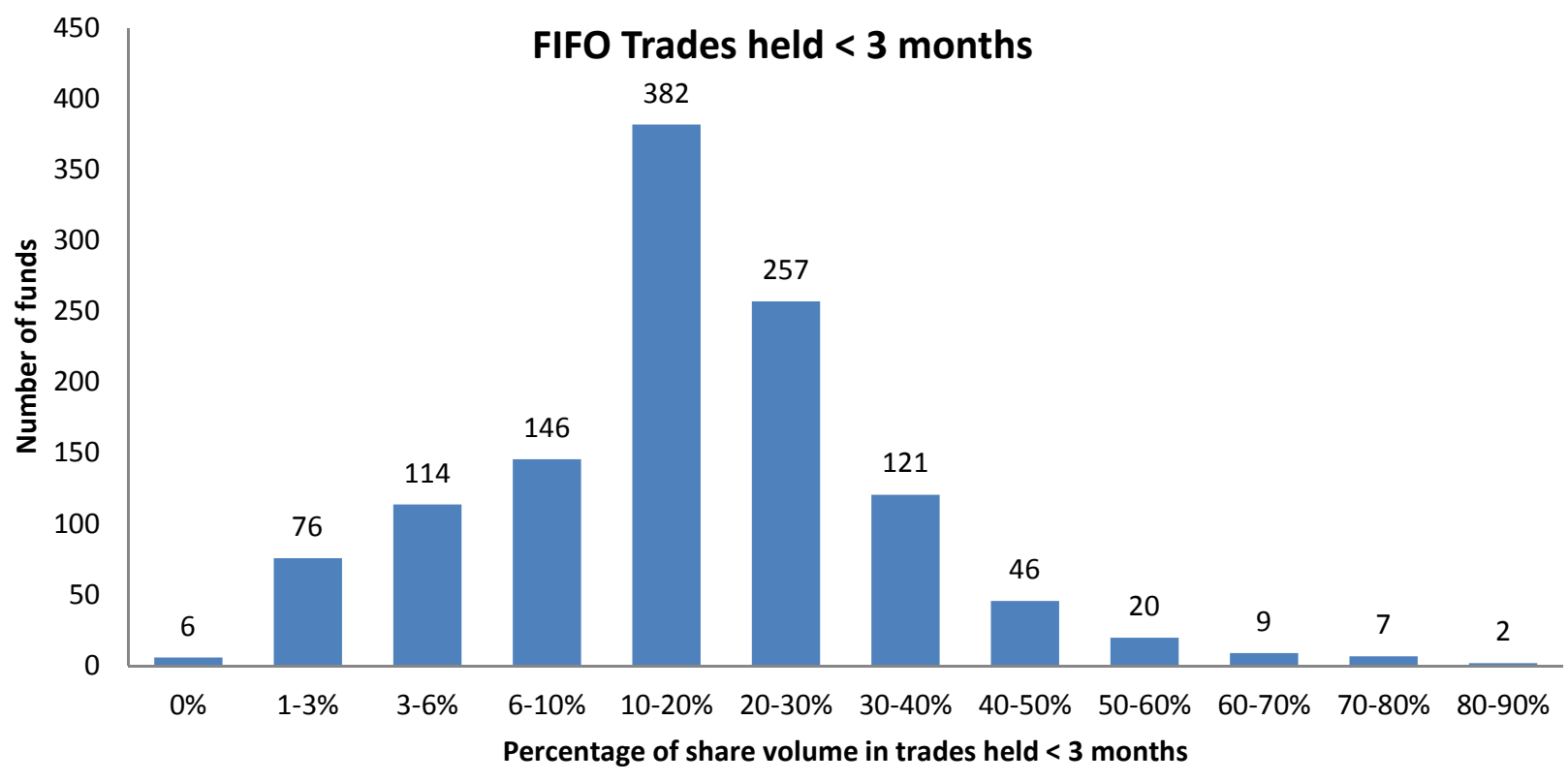

\section{LIFO Trades held $<3$ months}

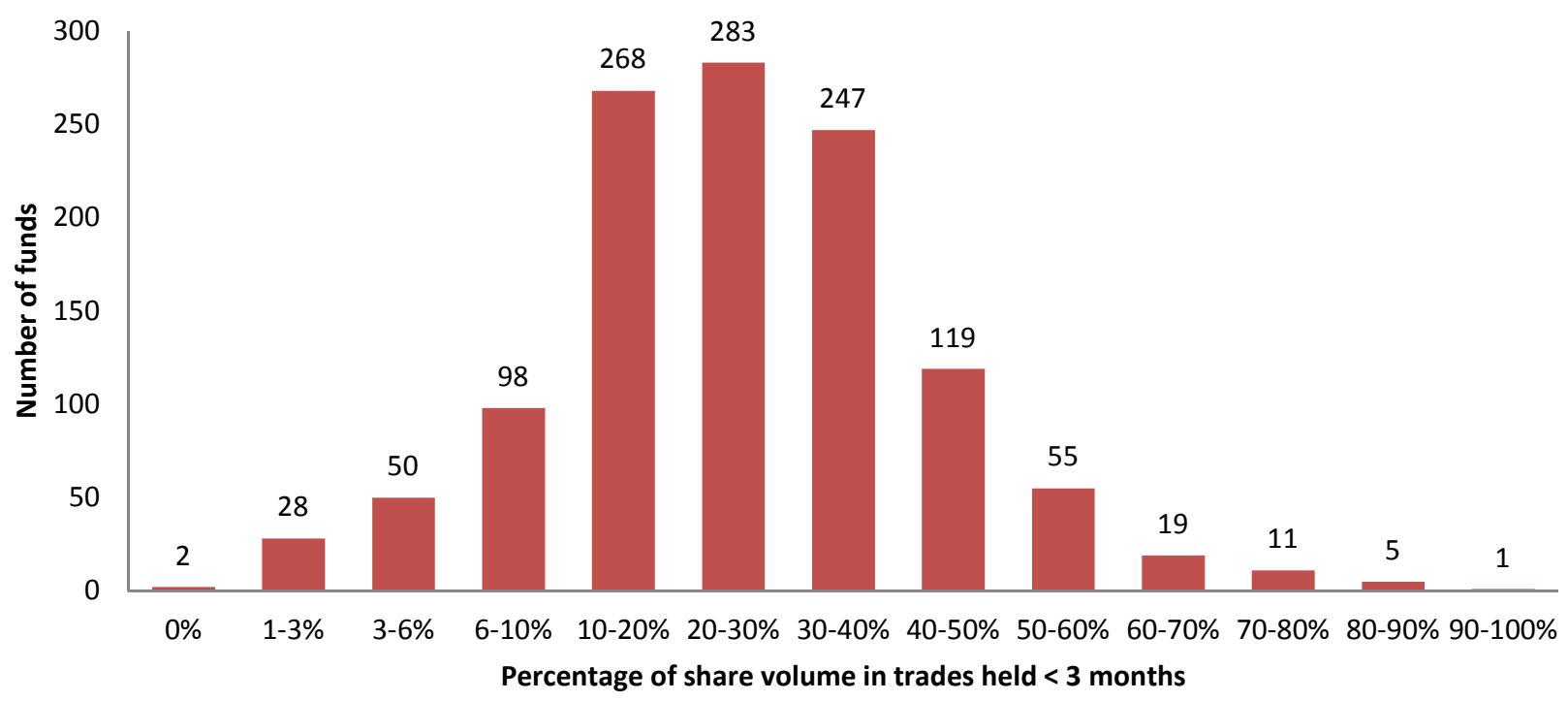




\section{The Performance of Short-term Institutional Trades}

\section{Online Appendix}

This appendix contains the following technical details and robustness checks related to the main paper:

Section A.1 Matching Ancerno trade records to CRSP data

Section A.2 Identifying Round-Trip Trades using FIFO versus LIFO methodology

Section A.3 Differences from Puckett and Yan (2011) Methodology

Section A.4 Implementation of double-clustered standard errors

Table A.1 Round-trip trades by holding period, full sample

Table A.2 Round-trip trade returns by holding period, full sample

\section{A.1 Matching Ancerno trade records to CRSP data}

Although the Ancerno data include identifiers for each stock, the variables named "ticker" and "cusip" are not the same as those used in databases such as CRSP, and different Ancerno clients report different tickers and cusips for the same stock. Ancerno provides a unique identifier for each stock - the stockkey - but this identifier is not present in CRSP. Because there is no linking variable that joins the CRSP and Ancerno data, we use a multi-step process to match firms in the Ancerno database to firms in the CRSP database. For every date, ticker, cusip, and stockkey combination in Ancerno, we match the Ancerno ticker to the CRSP permno using the ticker and cusip. For stockkey assignments that match multiple tickers, we generate a list of all the variations of the ticker symbol in Ancerno and match it to the most likely valid ticker from CRSP. For example, for the ticker AAPL in CRSP, Ancerno has AAPL, AAPL.OQ, AAPL US, AAPL.O, 
AAPL.NC, and several others. For all non-strict matches (in this example, AAPL.OQ, AAPL US, AAPL.O, and AAPL.NC), we compare the prices of the ticker AAPL to these other ticker symbol variations. If they exactly match in price on the same date, we assume that these are the same security - AAPL. Using this logic, we create a master file that produces a one-to-one match between each Ancerno stockkey and CRSP permno. We use this linking master file to merge the Ancerno records on daily institutional transactions to CRSP data.

\section{A.2 Identifying Round-Trip Trades using FIFO versus LIFO methodology}

To identify the FIFO-based (LIFO-based) round-trip trades, we assemble the transaction information for each symbol-clientcode-clientmgrcode combination chronologically into a queue, and when a transaction in the opposite direction enters the queue, we match it with the earliest (most recent) existing transaction in the queue. The number of trading days between the buy transaction and the sell transaction is the holding period of the round-trip trade, and the number of shares bought and sold (which are equal under the definition of a round-trip trade) is the roundtrip trade quantity. Below we provide examples of our FIFO and LIFO trade matching procedures.

Exhibit A.1 shows that clientmgrcode (fund) 131 of clientcode (institution) 515 made ten purchases (and no sales) of the stock Amgen Inc. (symbol = AMGN) over the period March 19, 1998 through December 16, 1998, at prices ranging from a low of $\$ 56.56$ to a high of $\$ 86.22$. Then on March 25, 1999, this fund made two sales of AMGN, one at $\$ 75.27$ for 500 shares and the other at $\$ 75.14$ for 2400 shares. 


\section{Exhibit A.1: Buy and sell transactions}

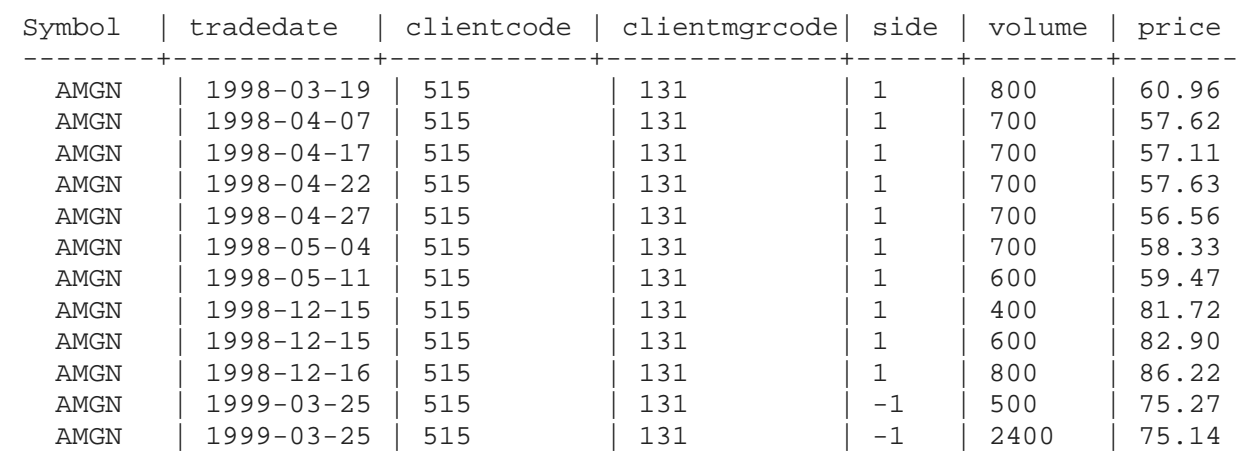

Exhibit A.2 presents the round-trip trades arising from the buy and sell transactions in Exhibit 2 using FIFO matching. From March 19 through December 16, 1998, all the buy transactions enter our transaction queue. Since there are no sell transactions for this symbolclientcode-clientmgrcode combination in 1998, there are no round-trip trades in 1998. We match the first sell transaction for 500 shares on March 25, 1999 (tradedate) to the first buy transaction in our queue, which occurred on March 19, 1998 (matchtradedate), to generate the first round-trip trade of 500 shares. The holding period (rtdays) for this round-trip trade is 257 trading days, the buy price ( $b p$ ) is $\$ 60.96$, and the sell price ( $s p$ ) is $\$ 75.27$. The next sale of 2400 shares is matched to the 300 shares left over from the trade on March 19, 1998, and three transactions of 700 shares each, on April 7, April 17, and April 22, 1998. There are 3,800 shares left in the queue, ready to be matched against incoming sell transactions.

$\underline{\text { Exhibit A.2: FIFO-matched round-trip trades }}$

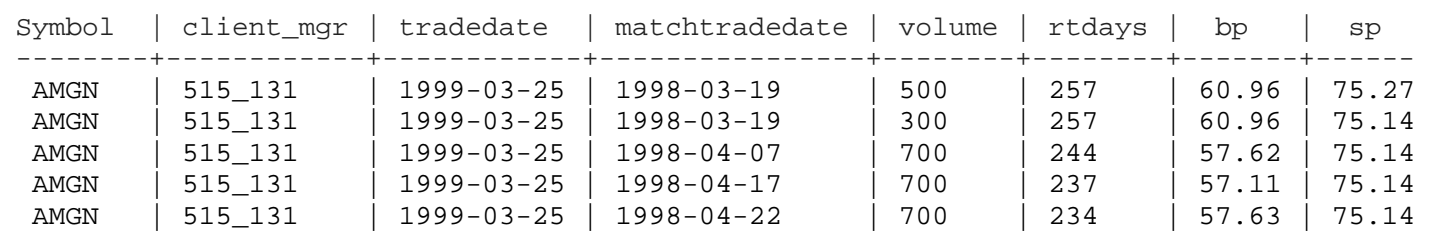


Exhibit A.3 presents the round-trip trades arising from the buy and sell transactions in Exhibit A.1 using LIFO matching. The difference from the FIFO matching procedure is that under LIFO, when a transaction in the opposite direction enters the queue, we match it with the most recent (rather than the earliest) existing transaction in the queue.

$\underline{\text { Exhibit A.3: LIFO-matched round-trip trades }}$

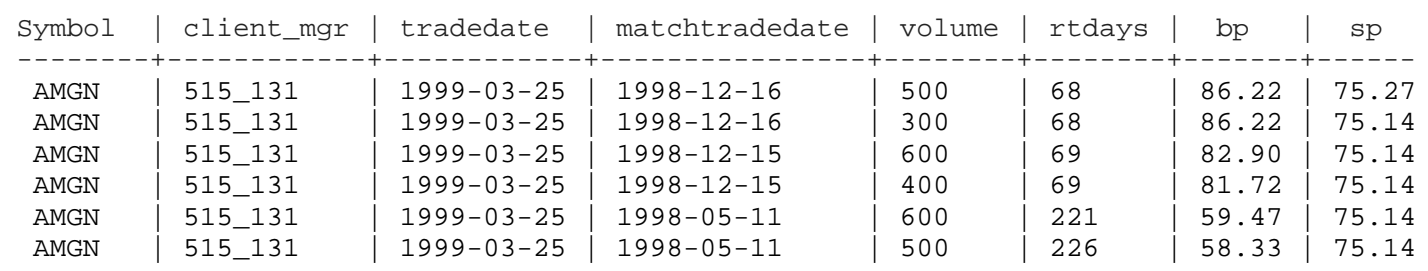

As in this example, the FIFO and LIFO methodologies generally lead to different roundtrip trade matching. ${ }^{1}$ We conduct all of our analyses on both sets of round-trip trades, and where the results for FIFO- and LIFO-based round-trip trades differ materially we present and discuss both.

\section{A.3 Differences from Puckett and Yan (2011) Methodology}

Exhibit A.4 presents a stylized example to highlight the differences in how intra-quarter round-trip trades are identified under the Puckett and Yan (PY) methodology versus our two methods (Our FIFO and Our LIFO). We examine a hypothetical fund's series of buys and sells in one stock in the second quarter of 2000, to show how different patterns of trading prior to the quarter of interest can lead to different intra-quarter trade identifications under the three methods. To illustrate the differences we assume the fund had no transactions in the stock prior to February 2000, and we change only the transaction that occurred in March 2000, one month before the

\footnotetext{
1 The two methods would yield identical sets of round-trip trades only if a fund executes either only one buy and one sell transaction in a stock or alternating buy and sell transactions of identical size for the entire period, which rarely occurs in practice.
} 
quarter of interest. The brackets indicate which buy is matched to which sell under each method, and " $y$ ” indicates that the resulting trade is an intra-quarter trade, " $n$ " that it is not.

\begin{tabular}{|c|c|c|c|c|}
\hline \multicolumn{5}{|c|}{$\begin{array}{l}\text { Exhibit A.4: Comparis on of round-trip trade matching under } \\
\text { Puckett and Yan (PY) vs Current Paper (Our) }\end{array}$} \\
\hline Case 1: & & \multicolumn{3}{|c|}{$\begin{array}{l}\text { Is there an Intra-quarter round-trip trade } \\
\text { in Q2 2000? }\end{array}$} \\
\hline Date & Shares (+ Buy, -Sell) & PY & Our FIFO & Our LIFO \\
\hline \multicolumn{5}{|c|}{ Jan-00 } \\
\hline $\mathrm{Feb}-00$ & 100 & & & \\
\hline Mar-00 & -100 & & & \\
\hline Apr-00 & 100 & 7 & 7 & 7 \\
\hline May-00 & -100 & ] & ]$_{\mathbf{y}}$ & ] \\
\hline Jun-00 & & & & \\
\hline
\end{tabular}

\begin{tabular}{|r|r|r|r|r|}
\hline Case 2: & & $\begin{array}{r}\text { Is there an Intra-quarter round-trip trade } \\
\text { in Q2 2000? }\end{array}$ \\
\hline Date & Shares (+ Buy, -Sell) & PY & Our FIFO & Our LIFO \\
\hline Jan-00 & & & & \\
\hline Feb-00 & 100 & & & \\
\hline Mar-00 & 100 & & & \\
\hline Apr-00 & 100 & 7 & & \\
\hline May-00 & -100 & & & \\
\hline Jun-00 & & & & \\
$\mathbf{n}$ & & \\
\hline
\end{tabular}

\begin{tabular}{|r|r|r|r|r|}
\hline Case 3: & & $\begin{array}{r}\text { Is there an Intra-quarter round-trip trade } \\
\text { in Q2 2000? }\end{array}$ \\
\hline Date & Shares (+ Buy, -Sell) & PY & Our FIFO & Our LIFO \\
\hline Jan-00 & & & & \\
\hline Feb-00 & 100 & & 7 & \\
\hline Mar-00 & -200 & & & \\
\hline Apr-00 & 100 & 7 & & \\
\hline May-00 & -100 & & & \\
\hline Jun-00 & & & & \\
\hline
\end{tabular}

In Case 1, the three methods produce the same round-trip trades in the second quarter. The round-trip trades are of the same length and size under all three methods. In the remaining two cases, the PY method produces the same intra-quarter trade in the second quarter, because it 
considers only transactions within the quarter, while the changing pattern of transactions before the second quarter can lead to different round-trip trade matching under our methods.

In Case 2, our LIFO method produces the same round-trip trade as PY, with the 100 shares sold in May matched to the 100 shares bought in April, but the FIFO method links the sell in May to the first buy in the queue, from February 2000, so the round-trip trade is not intra-quarter. The trades are also unlikely to have the same returns unless the February price is the same as the April price.

In Case 3, neither our FIFO nor our LIFO method identifies an intra-quarter round-trip trade in the second quarter. Instead, the 100-share purchase in April is linked to the 200 shares sold in March (the prior quarter), which can be either a short sale or a sale from a baseline portfolio position where the manager has made marginal trades.

\section{A.4 Implementation of double-clustered standard errors}

Short-duration round-trip trade returns may be correlated over time and/or across funds or stocks, so using standard $t$-statistics may overstate significance. To account for dependencies both in the cross section and over time, all of the $t$-statistics reported in our analyses are based on standards errors that are clustered on both time and fund (or stock), following Thompson (2011). In this section we outline how we implement the double-clustered standard errors for trades or funds within a single quintile and then for tests of the differences between trades or funds in the top versus bottom quintile. We illustrate the methodology using the example of the return persistence analysis in Table 5, which includes both individual quintile and quintile difference tests. $^{2}$

\footnotetext{
${ }^{2}$ Code for calculating the standard errors can be derived from Thompson (2011) or is available on request from the authors, who thank Andy Puckett for sharing his code with them as well.
} 
Individual quintile. For the funds in each quintile, we run the following regression:

$$
\operatorname{Return}_{f, t}=\alpha+\varepsilon_{f, t}
$$

where Return $_{f, t}$ is the average return for short-duration trades in fund $f$ in semiannual period $t$; $\alpha$ is a constant, and $\varepsilon_{f, t}$ is the error term. The estimated $\alpha$ is the average value, and its $t$-statistic is computed using the double-clustered standard error methodology of Thompson (2011), clustering on fund $(f)$ and semiannual period $(t)$.

Difference between quintiles. We first stack all of the Returnf,t observations for Quintile 1 and Quintile 5 into one panel, adding a new variable Topf,t which is equal to 1 for observations from Quintile 5, else zero. We then run the following regression:

$$
\operatorname{Return}_{f, t}=\alpha+\beta \operatorname{Top}_{f, t}+\varepsilon_{f, t}
$$

The estimated coefficient $\beta$ is the average difference, and the $t$-statistic for $\beta$ is computed using the double-clustered standard error methodology of Thompson (2011), clustering on fund ( $f$ ) and semiannual period $(t)$.

\section{REFERENCES}

Puckett, A., and X. Yan, 2011, The interim trading skills of institutional investors, Journal of Finance 66, 601-633.

Thompson, S., 2011, Simple formulas for standard errors that cluster by both firm and time, Journal of Financial Economics 99, 1-10. 
Table A.1: Round-trip trades by holding period, full sample

Institutional trading data are from Ancerno Ltd. for trades executed between January 1, 1999, and December 31, 2009 by all funds in the database. Panel A presents statistics based on round-trip trades defined using FIFO methodology; Panel B presents statistics based on round-trip trades defined using LIFO methodology. Holding period refers to the time between when a trade is initiated and when it is unwound. The columns labeled Aggregate Shares present percentages calculated across all round-trip trades in each category; the columns labeled Fund-level Cumulative Percentages present statistics about the cumulative percentages of share volume in trades with holding periods less than or equal to the period specified, across the funds in each sample.

Panel A: FIFO round-trip trades

\begin{tabular}{|c|c|c|c|c|c|c|c|}
\hline & & & & \multicolumn{4}{|c|}{ Fund-level Cumulative Percentages (\%) } \\
\hline \multicolumn{2}{|c|}{ Holding Period } & \multicolumn{2}{|c|}{ Aggregate Shares } & \multicolumn{2}{|c|}{ Money Manager } & \multicolumn{2}{|c|}{ Pension } \\
\hline At least & Less than & $\%$ & Cumulative \% & Mean & Median & Mean & Median \\
\hline 1 day & 1 week & 1.60 & 1.60 & 0.00 & 0.00 & 0.00 & 0.00 \\
\hline 1 week & 1 month & 6.51 & 8.11 & 5.66 & 1.80 & 2.40 & 0.22 \\
\hline 1 month & 2 months & 8.84 & 16.94 & 22.09 & 12.06 & 11.85 & 5.17 \\
\hline 2 months & 3 months & 8.32 & 25.26 & 39.05 & 27.02 & 24.76 & 16.07 \\
\hline 3 months & 4 months & 7.69 & 32.96 & 49.55 & 40.00 & 35.28 & 26.92 \\
\hline 4 months & 5 months & 6.97 & 39.92 & 56.29 & 50.19 & 44.08 & 37.48 \\
\hline 5 months & 6 months & 6.11 & 46.03 & 61.96 & 57.24 & 51.52 & 47.56 \\
\hline 6 months & 9 months & 14.63 & 60.66 & 67.05 & 63.90 & 57.67 & 56.00 \\
\hline 9 months & 1 year & 10.31 & 70.97 & 76.49 & 77.93 & 71.38 & 75.70 \\
\hline 1 year & 2 years & 18.61 & 89.58 & 82.94 & 87.26 & 79.74 & 87.11 \\
\hline 2 years & 3 years & 6.17 & 95.75 & 94.94 & 99.37 & 93.67 & 100.00 \\
\hline 3 years & 4 years & 2.38 & 98.13 & 98.32 & 100.00 & 97.60 & 100.00 \\
\hline 4 years & & 1.87 & 100.00 & 99.22 & 100.00 & 99.01 & 100.00 \\
\hline
\end{tabular}

Panel B: LIFO round-trip trades

\begin{tabular}{|c|c|c|c|c|c|c|c|}
\hline & & & & \multicolumn{4}{|c|}{ Fund-level Cumulative Percentages (\%) } \\
\hline \multicolumn{2}{|c|}{ Holding Period } & \multicolumn{2}{|c|}{ Aggregate Shares } & \multicolumn{2}{|c|}{ Money Manager } & \multicolumn{2}{|c|}{ Pension } \\
\hline At least & Less than & $\%$ & Cumulative \% & Mean & Median & Mean & Median \\
\hline 1 day & 1 week & 11.59 & 11.59 & 11.52 & 7.02 & 3.27 & 0.65 \\
\hline 1 week & 1 month & 16.42 & 28.01 & 32.65 & 25.77 & 15.31 & 8.78 \\
\hline 1 month & 2 months & 12.36 & 40.37 & 49.92 & 43.53 & 29.86 & 22.51 \\
\hline 2 months & 3 months & 8.70 & 49.07 & 60.13 & 54.76 & 40.94 & 34.71 \\
\hline 3 months & 4 months & 6.68 & 55.76 & 66.38 & 63.51 & 49.81 & 45.71 \\
\hline 4 months & 5 months & 5.43 & 61.19 & 71.23 & 68.99 & 57.05 & 55.08 \\
\hline 5 months & 6 months & 4.45 & 65.64 & 75.00 & 73.90 & 62.84 & 62.63 \\
\hline 6 months & 9 months & 9.61 & 75.25 & 82.55 & 84.38 & 75.28 & 79.74 \\
\hline 9 months & 1 year & 6.38 & 81.62 & 87.43 & 89.69 & 82.72 & 88.90 \\
\hline 1 year & 2 years & 11.42 & 93.05 & 96.21 & 99.25 & 94.68 & 100.00 \\
\hline 2 years & 3 years & 3.90 & 96.95 & 98.65 & 100.00 & 97.94 & 100.00 \\
\hline 3 years & 4 years & 1.66 & 98.61 & 99.37 & 100.00 & 99.14 & 100.00 \\
\hline 4 years & & 1.39 & 100.00 & 100.00 & 100.00 & 100.00 & 100.00 \\
\hline
\end{tabular}




\section{Table A.2: Round-trip trade returns by holding period, full sample}

Institutional trading data are from Ancerno Ltd. for trades executed between January 1, 1999, and December 31, 2009 by all funds. The table reports FIFO round-trip trade average raw returns that are weighted by principal amount (initial share price times number of shares) within each holding period category. Raw return is the percentage price change over the holding period. Means and medians in bold are significantly different from zero with a p-value less than 0.01 ; means and medians in italics are significantly different from zero with a pvalue less than 0.05 .

\begin{tabular}{|c|c|c|c|c|c|c|c|c|c|c|}
\hline \multirow{2}{*}{\multicolumn{2}{|c|}{ Holding Period }} & \multirow{3}{*}{$\begin{array}{l}\text { Aggregate } \\
\text { Trade } \\
\text { Returns } \\
\end{array}$} & \multicolumn{8}{|c|}{$\begin{array}{cc}\text { Fund-level Trade Returns } \\
\end{array}$} \\
\hline & & & \multicolumn{4}{|c|}{ Money Managers } & \multicolumn{4}{|c|}{ Pension Funds } \\
\hline At least & Less than & & Mean & Median & 25th P'tile & 75th P'tile & Mean & Median & 25th P'tile & h P'tile \\
\hline 1 day & 1 week & -0.97 & -0.64 & -0.40 & -1.35 & 0.55 & -1.30 & -0.45 & -4.25 & 2.01 \\
\hline 1 week & 1 month & -2.70 & -2.12 & -1.51 & -3.93 & -0.11 & -2.28 & -1.85 & -7.33 & 2.14 \\
\hline 1 month & 2 months & -3.88 & -1.94 & -2.19 & -5.46 & 1.03 & -2.79 & -2.15 & -8.67 & 3.29 \\
\hline 2 months & 3 months & -5.17 & -1.03 & -1.35 & -6.74 & 3.26 & -2.19 & -2.59 & -9.37 & 4.42 \\
\hline 3 months & 4 months & -4.91 & -3.13 & -2.77 & -7.36 & 2.39 & -2.18 & -2.40 & -10.33 & 5.32 \\
\hline 4 months & 5 months & -5.29 & -2.38 & -2.52 & -7.46 & 4.13 & -2.36 & -2.59 & -11.14 & 6.02 \\
\hline 5 months & 6 months & -5.34 & -1.31 & -2.47 & -7.99 & 4.30 & -1.36 & -2.44 & -11.76 & 6.32 \\
\hline 6 months & 9 months & -4.77 & -1.85 & -2.45 & -8.44 & 4.11 & -1.58 & -1.93 & -11.36 & 7.41 \\
\hline 9 months & 1 year & -4.42 & -1.75 & -0.82 & -8.94 & 4.85 & -0.82 & -0.99 & -12.45 & 9.25 \\
\hline 1 year & 2 years & -2.43 & 0.38 & 0.12 & -9.08 & 6.04 & 0.30 & 0.97 & -12.50 & 13.15 \\
\hline 2 years & 3 years & 1.37 & 0.73 & 1.85 & -6.76 & 12.62 & 1.19 & 3.56 & -13.04 & 18.76 \\
\hline 3 years & 4 years & 6.66 & 3.27 & 8.28 & -9.44 & 23.65 & 3.78 & 6.18 & -16.12 & 25.75 \\
\hline 4 years & & 11.09 & 4.49 & 8.73 & -14.18 & 24.89 & 6.99 & 10.58 & -12.00 & 31.39 \\
\hline
\end{tabular}

